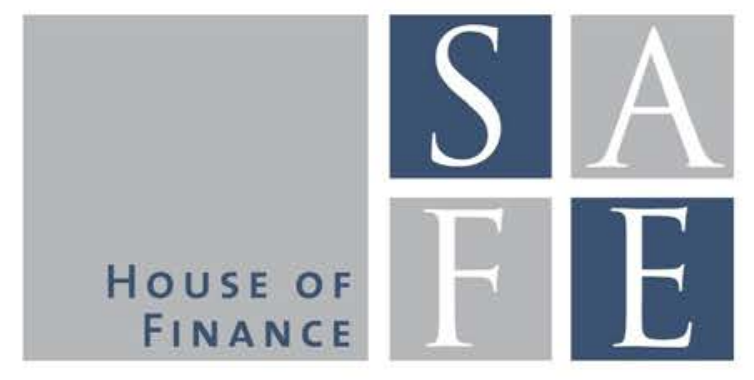

WORKING PAPER SERIES

Zsuzsa R. Huszár - Zorka Simon

\title{
The Pricing Implications of the Oligopolistic Securities Lending Market: A Beneficial Owner Perspective
}

SAFE Working Paper No. 215

SAFE I Sustainable Architecture for Finance in Europe A cooperation of the Center for Financial Studies and Goethe University Frankfurt 


\section{Non-Technical Summary}

After the global financial crisis, institutions have gradually moved from the unsecured interbank lending market to the repo markets to cover their funding needs. At the same time, while the supply of high quality liquid assets (HQLA) began to shrink with banks' reduced risk taking and window-dressing, the demand grew with the shift towards derivative clearing via central counterparties. This created interest in large-scale collateral swaps, upgrading low quality assets to fixed income HQLA in the securities lending market. These market forces and lenders' growing awareness to generate alternative income from passive assets through securities lending gave rise to a multi-trillion dollar fixed income segment in the global securities lending market. In this study, we focus on the primary and secondary market for German treasuries and discuss the negative welfare implications arising from the still nontransparent oligopolistic securities lending market.

We first show that in the primary market, prime broker bidding group members may artificially inflate the prices of HQLA in search of scarce safe assets, disadvantaging long-term investors, such as pension funds and insurance firms, who have to gain access to these assets. More importantly, in examining the pricing implications in the secondary market, we show that prime brokers acting as lending agents for pension funds may exploit their information advantage, and do not fully compensate these lenders with limited bargaining power.

Overall, we suggest that the artificially depressed yields for safe European sovereign bonds in combination with the inherent inefficiencies in the securities lending market have important negative welfare implications for the European pension system. Pension funds and insurance firms struggle to generate returns or alternative lending income from securities lending, while on the other hand being responsible for preserving wealth and managing retirement savings for the majority of European citizens.

Our results have important policy implications. We suggest that pension funds and insurance firms need to become more proactive by either managing their own lending desk or by lobbying for more regulatory oversight and greater transparency to improve their bargaining power. From a welfare perspective, we suggest that it is inefficient to restrict pension funds to purchase treasuries in the secondary market through prime broker-dealers because this exposes them to significant direct and indirect costs, which in the end are borne by the pensioners. 


\title{
The Pricing Implications of the Oligopolistic Securities Lending Market:
}

\section{A Beneficial Owner Perspective}

\section{Zsuzsa R. Huszár and Zorka Simon ${ }^{1}$}

Current Draft: June 15, 2018

\begin{abstract}
In the last decade, central bank interventions, flights to safety, and the shift in derivatives clearing resulted in exceptionally high demand for high quality liquid assets, such as German treasuries, in the securities lending market besides the traditional repo market activities. Despite the high demand, the realizable securities lending income has remained economically negligible for most beneficial owners. We provide empirical evidence of pricing inefficiencies in the non-transparent, oligopolistic securities lending market for German treasuries from 2006 to 2015. Consistent with Duffie, Gârleanu and Pedersen (2005)'s theory, we find that the less connected market participants' interests are underrepresented, evident in the longer maturity segment, where lenders are more likely to be conservative passive investors, such as pension funds and insurance firms. The low price elasticity in this segment hinders these beneficial owners to fully capitalize on the additional income from securities lending, giving rise to important negative welfare implications.
\end{abstract}

JEL classification: G12, G18, G21, G23

\footnotetext{
${ }^{1}$ The authors thank Roel Beetsma (discussant), Edina Berlinger (discussant), Ekkehart Boehmer, Giuseppe Cappelletti (discussant), Huang Dashan, Alexander Eisl (discussant), Bálint L. Horváth, Markus Huggenberger, Thomas Kick (discussant), Yue Ling, Roger K. Loh, Pippa Lowe, Ernst Maug, David M. Reeb, Johan Sulaeman, Weina Zhang, and all seminar and conference participants at the German Finanzagentur, the University of Mannheim, National University of Singapore (NUS), Singapore Management University (SMU), Goethe University Frankfurt, 2017 Summer Workshop of the Hungarian Academy of Sciences (MTAKTI), IRMC 2017 Florence, IFABS 2017 Oxford Conference, 2017 FMA Boston, $8^{\text {th }}$ AFML Conference in Budapest, 2018 Netspar International Pension Workshop, 2018 Consob-Bocconi- ESMA conference, Securities Markets: Trends, Risks and Policies, and the $5^{\text {th }}$ International Conference on Sovereign Bond Markets at the Bank of Canada.
}

Huszár is at the National University of Singapore, email: Zsuzsa.r.huszar@gmail.com and Tel: +65 98366122. Simon is at the Research Center SAFE, Goethe University Frankfurt, email: simon@safe.uni-frankfurt.de and Tel: +49 69798 33704. Huszár acknowledges the generous financial support from NUS start-up grant and thanks IHS Markit for providing data on the bonds securities lending market. Simon gratefully acknowledges research support from the Research Center SAFE, funded by the State of Hessen initiative for research LOEWE. 


\section{Introduction}

After the global financial crisis, institutions have gradually moved from the unsecured interbank lending market to the securities lending and repo markets to cover their funding needs. Consequently, by 2016, the fixed income segment of the securities lending market has become a five-trillion dollar business (ISLA, 2016). The fixed income segment, similarly to the equity segment, operates primarily as a non-transparent oligopolistic OTC market, with about a dozen key prime brokers or agents connecting the supply and demand sides. This setting likely gives rise to market inefficiencies, where less connected borrowers are known to receive inferior borrowing terms, as recently documented by Chague et al. (2016) among others. ${ }^{1}$

The extant securities lending market studies tend to focus on the borrower side in the equity segment because the borrowers are short sellers, who play an economically important role in the price discovery process in the stock market (Boehmer and $\mathrm{Wu}, 2013$ ). However, the same market inefficiencies are likely to be also present on the lender side. Prime brokers or agents exploiting their information advantage and market power on the lender's side is not only in line with Duffie et al. (2002; 2005)'s work but it is also confirmed by U.S. lawsuits filed by pension funds (SLT, 2010c; Reuters, 2017). The welfare implications of market inefficiencies from the lenders' perspective are even more acute in the fixed income segment, where the lenders (beneficial owners) are likely to be pension funds and insurance firms, responsible for the wealth preservation of citizens worldwide. These institutions are mandated to hold a large sovereign debt portfolio, while their risk taking is limited by

\footnotetext{
${ }^{1}$ Duffie, Gârleanu, and Pedersen (2002; 2005) and Kolasinski, Reed, and Ringgenberg (2013) theoretically and empirically examine how search costs in the oligopolistic OTC lending market gave rise to inefficiencies. Internationally, Saffi and Sigurdsson (2011) show that a developed stock lending market is necessary to support short selling, while Boehmer and $\mathrm{Wu}$ (2013) and Gagnon and Wittmer (2014) show that these shortsale trades are important for pricing efficiency for US and cross-listed stocks. Despite the various attempts to establish centralized and more transparent markets by exchanges (e.g., Singapore Exchange) and private companies (e.g., SecFinex and more recently Quadriserv), the securities lending market today still remains primarily a bilateral or tri-party OTC arrangement through prime broker-agents (SLT, 2010a; 2010b).
} 
regulation, making them extremely sensitive to the low interest environment, and increasingly reliant on alternative income from securities lending. ${ }^{2}$

In reaction to the global financial crisis and the European debt crisis, central banks and government agencies have become active in financial markets, especially as they realized that conventional monetary policy tools do not work at the zero lower bound. Among others, the European Central Bank (ECB) and a number of European national central banks began active purchase programs targeting a wide range of assets as part of their quantitative easing $(\mathrm{QE})$ efforts. These asset purchases, aiming at decreasing funding costs, drove up the price of sovereign debt assets, especially at the lower end of the sovereign risk spectrum, where demand was exacerbated by flights to safety and quality. The artificially depressed funding costs and the market exuberance emanating from the emergence of the Internet of Things and the sharing economy resulted in unprecedented stock market run-ups globally, benefiting corporations and shareholders alike.

However, conservative investors, such as pension funds and insurers often missed out on the gains from the favorable market conditions because the regulatory restrictions on their asset holdings limited their equity investments (e.g., MiFID II; Directive 2003/41/EC, EU Directive 2016/2341; IORP Directive). European pension funds gradually reduced their equity allocation to levels below 40\% after 2006 (Mercer, 2014) by accumulating more longterm safe debt assets. ${ }^{3}$ At the same time, the acquisition of HQLA became increasingly expensive. In this situation, the average European citizen, primarily relying on pension income at old age, might have to bear some of the costs of the economic stimulus, unless

\footnotetext{
${ }^{2}$ For simplicity, we use beneficial owners and lenders interchangeably in the text. The effective de-facto lenders are however often the prime brokers and the agents acting on behalf of the owners, who may not have the capability (e.g., lending facility) to lend directly.

${ }^{3}$ While in the low interest rate environment, the valuation of pension funds' assets is positively affected, pension funds in the absence of active trading can only realize paper gains. Still, as the regulatory discount rates did not change, coverage ratios improved, potentially alleviating the growing stress on the pension assets in the short term.
} 
pension funds leverage on the securities lending market for addition income to offset the rising costs of securing HQLA assets.

In this paper, to our knowledge, we are the first to explicitly examine the welfare implications of the European zero lower bound interest rate policy in conjunction with the functioning of the securities lending market for German nominal bonds from July 2006 to June 2015. In a relevant paper, Aggarwal et al. (2016) also examine treasury securities lending activities in Europe, where the authors focus on the interaction of the repo and securities lending markets to reveal important funding liquidity implications from a macroeconomic policy perspective. Our paper has a different focus, the passive beneficial owners' perspective, where the efficacy of the securities lending market can be directly linked with citizens' wealth preservation.

As a result of government interventions and regulatory changes, high demand for high quality liquid assets (HQLA) emerged, which unintentionally forced long-term conservative investors to buy safe government bonds at potentially inflated prices from prime brokers. Theoretically, the demand pressure in the primary and secondary market for HQLA could generate significant alternative income from securities lending for beneficial owners over the long investment horizon. However, well-documented market inefficiencies, such as the inelasticity of lending fees (Kolasinski et al., 2013) and the low bargaining power of less connected pension funds, may impede the realization of significant revenues, as suggested by recent lawsuits filed by pension funds (SLT, 2010a, 2010b; Reuters, 2017; WSJ, 2017).

In our empirical analysis, we review the life-cycle of safe treasury investments from a conservative beneficial owner's perspective. We start by explaining the functioning of the securities lending market (in contrast with the repo market) where long-term investors can earn additional income besides regular coupon payments on their passive assets. After the general introduction, we explore a German Treasury bond investment from the initial 
purchase throughout the lifecycle of holding the assets, where agency conflicts between the prime broker-agents and lenders can have detrimental effects on the profitability and risk of the investment. In the primary auction setting, we show that the excess demand for the increasingly scarce HQLA drives up the prices of German bonds, perhaps beyond the expected future lending income that would be consistent with rational market expectations (Duffie et al., 2002). At this stage, we also document that, on average, the realizable or expected lending income is negligible for the average lender with limited market insight and bargaining power; thus, the brokers' bidding is not aligned with the lender/ultimate beneficial owner's interest.

In the second part of the empirical analysis, we attempt to shed light on the efficiency of the securities lending market from the beneficial owners' perspective during the multiyear holding period of a German Treasury bond. We focus on the long maturity segment, where the welfare implications are evident because the beneficial owners are expected to be pension funds and insurance firms responsible for the wealth preservations of the average citizen. We find evidence of market inefficiency by documenting a sluggish reaction of lending fees to demand pressure, despite exceptionally high utilization rates in this segment. Furthermore, we also show high relative price spreads on lending contracts, especially when fees are high. This suggests that some lenders, potentially those without active lending desks, such as the pension funds and insurance firms, are unable to extract the "real" rents because prime brokers capitalize on their information advantage and market power. These findings are consistent with recent legal complaints by smaller U.S. pension funds, who claim receiving insufficient compensation from securities lending (Reuters, 2017).

Overall, we provide new insights into the inefficiencies of the securities lending market for fixed income assets. We suggest that passive lenders need to become more active by either managing their own lending desk or by lobbying for more regulatory oversight and 
greater transparency to improve their bargaining power. Alternatively, regulators may consider extending the pool of HQLAs, thereby reducing the price pressure on these assets, or establishing channels through which the funds get access to sovereign bonds directly from the issuer. From a welfare perspective, we suggest that it is inefficient to restrict pension funds to purchase treasuries in the secondary market through dealers because this exposes them to significant direct and indirect costs, which in the end are borne by pensioners.

\section{Introduction to Securities Lending and its Role for Wealth Preservation}

\subsection{Introduction to Securities Lending from the Lenders' perspective}

Due to their increased liquidity provisional and liquidity transformational role, the repo and securities lending markets warrant academic and regulatory attention (Agarwal et al. 2016; Arnesen, 2017). For fixed income securities, the repo market has attracted much academic attention due to its liquidity provisional role. Financial institutions heavily rely on repo financing, where they use high quality treasuries to secure overnight or short term financing at a low, so-called general collateral (GC) rate. In these supply-driven transactions, the owner of the treasury lends out the asset at a discount. However, in some cases the demand for specific treasuries gives rise to specialness, where specific treasuries can be lent out at a high rate, in which case the lending transaction is driven by the demand side of the market.

Securities lending (SL) transactions are like repos, a type of securities financing transactions (SFT). The two types of instruments have many similarities and can often be used as substitutes for each other, where the main difference is that while repo is supplydriven, the SL transaction is demand-driven, where the owner of the asset is not liquidity constrained and wants to lend out its asset only at a premium (not at a discount). In SL, the beneficial owner lends out asset X, normally in an overnight transaction, where the borrower posts collateral in access of $102-104 \%$ depending on the quality of the collateral or the 
specific local regulatory environment. However, comparing SL and repo transactions, Figure 1 suggests that there is an overlap between securities lending and the "specials" segment of the repo market, which is also driven by the demand to borrow particular securities.

[Figure 1 about here]

In a securities lending transaction in the international market, as in repo, one party gives legal title to a security or basket of securities to another party for a limited period of time, in exchange for legal ownership of the collateral. The first party is called the "lender", even though she is transferring the legal title to the other party. Similarly, the other party is called the "borrower", even though she is taking legal title of the security (ICMA, 2018). The other important difference is that in securities lending the fee is generally agreed daily, and it is shared between the agent and the lender (beneficial owner), especially when the collateral is a security that cannot be easily reinvested for additional revenue. While in cases, when the collateral is cash or other liquid security, a rebate rate will be negotiated between the lending agent and the borrower. ${ }^{4}$

"This rebate rate, stated as an interest rate, represents the interest on the borrower's cash collateral that the lending agent agrees to pay back to them at the termination of the loan. In order to generate a yield, the lending agent will invest the cash via a commingled fund or in a separate account in short-term fixed income instruments in order to generate a spread above the rebate rate. The difference between the yield on the cash collateral and the rebate rate is the revenue that will be shared between the lender and their lending agent. Consequently, lenders should be aware of the market risk (JP Morgan, 2011)."

Globally, securities lending contracts are predominantly OTC transactions, where lenders and borrowers are connected through agents and/or prime brokers, which results in a high

\footnotetext{
${ }^{4}$ Traditionally, cash collateral is used in the U.S. and non-cash securities in Europe and Asia. Depending on the credit quality and liquidity of the non-cash collateral re-hypothecation or collateral re-pledging might be feasible, which could further enhance the income generating potential of SL transactions.
} 
degree of opaqueness. ${ }^{5}$ Although there have been efforts to establish a centralized and more transparent securities lending market, such as SecFinex, we have yet to see this becoming the norm. In the current oligopolistic market setting, about a dozen prime brokers/agent lenders control their own significant market share. In fact, this gives rise to high search costs, moreover, less connected borrowers or borrowers with limited bargaining power are often unable to arrange transactions to execute their trades (Duffie et al. 2002; 2005; Kolasinski et al. 2013). These inefficiencies are well-documented in the equity segment of the securities lending market because they cause binding short-sale constraints, which negatively affect market quality and market efficiency (e.g., Boehmer and Wu, 2013; Chague et al. 2017; Saffi and Sigurdsson, 2011). Thus far, these inefficiencies have not attracted much attention in the fixed income segment.

In recent years, the fixed income segment of the securities lending market became increasingly important for collateral swaps and CDS trades, where the demand for specific assets drives these transactions. Natural lenders are pension funds, trusts, and insurance firms, who hold large portfolios of assets passively, both in the equity and fixed income segments. According to the 2016 State Street report, these passive institutions account for about $75 \%$ of the lending supply in IHS Markit Data. Consequently, as State Street (2016) reports, in the persistently low interest rate environment securities lending has emerged as an important nonconventional source of income, where the received collateral is passed through to invest in potentially more profitable structured financing vehicles. This income source is especially valuable in the Eurozone, where most pension funds hold a large portfolio of sovereign debt,

\footnotetext{
5 Although there is a significant growth in CCP cleared securities lending contracts, which can reduce counterparty risk, thus far it has not significantly improved transparency. In January 2009, the OCC began centrally clearing all stock loan transaction on AQS, a wholly owned subsidiary of Quadriserv. Quadriserv is currently in the center of a heated debate, where pension funds are suing major banks which "tend" to boycott the system (Reuters, 2017).
} 
while since 2011, both nominal and real yields have been hovering around and below zero, respectively.

\subsection{A Pension Fund's Perspective on Securities Lending: Opportunities and Risks}

Financial institutions, such as insurance firms, pension funds and trusts, are the primary investors in treasuries. Pension funds and insurers play a key role in Europe, as the majority of retirees, to a large extent, rely on public or occupational pension income. Because the European pension and insurance sectors are economically essential, they are heavily regulated, and funds are required to hold a significant fraction of their portfolios in low-risk, fixed-income assets. For instance, the European Solvency II Directive promotes better risk management practices, which calls for greater exposure to long-term treasuries (IPE, 2016). This practice is strictly followed in the industry, as the 2014 Mercer survey finds that German pension funds allocate $42 \%$ of their total assets in domestic German government bonds (nonindexed, nominal assets). ${ }^{6}$ Although this regulatory push towards safe fixed income asset holding is to prevent significant value deterioration in market downturns, the historically low interest rates likely attributed to the European pension industry's aggregate net worth becoming negative for the first time in 2016 (ECB, 2016). ${ }^{7}$

As the example of the most innovative and active pension funds, such as California Public Employee's Retirement System (CalPERS) shows, engaging in securities lending can generate significant annual revenues from lending out passive assets to major financial institutions. The lending program of CalPERS has attracted much attention and was envied in the industry until the global financial crisis, when unexpected risks arose from unexpectedly

6 Corporate pension funds had $46 \%$ of their total assets in bonds while other pension funds not using CTAs (non-CTA funds) had $52 \%$ of their assets in bonds.

7 In extreme cases, for example, ERAFP (Retraite additionelle de la Fonction publique), which manages the French public service additional pension scheme, had to invest $75 \%$ of assets into bonds until 2015 , when the limit was lowered. In 2016, more than 50\% of the fund's assets were still in sovereign bonds (Global Pension Assets Study, 2016). The CEO of ERAFP, France's second largest pension fund, expressed concerns about the suboptimal portfolio allocation of the $€ 26$ billion portfolio of the fund (Bloomberg, 2016). 
risky collateral reinvestment, see Figure 4 for details. CalPERS actually has a well-developed securities lending program with strict guidelines, but even that system was not resilient to the 2007-2008 mortgage crisis (see Online Appendix C). The issue was that their lending agent, who received and reinvested the collateral on behalf of CalPERS in liquid, high credit quality fixed income assets according to the agreed guidelines, purchased Lehman notes. Although these notes fulfilled the basic requirements of CalPERS, in 2007-2008 defaulted, resulting in substantial losses from collateral reinvestment. This pushed beneficial owners to be more focused on the fee component of securities lending, especially in the low interest rate environment where the income generating function of collateral diminished (SLT, 2015).

\section{Data, Summary Statistics and Hypothesis Development}

\subsection{Data and Variable Constructions}

Our dataset contains daily bond yields of German treasuries from July 3, 2006 to June 1, 2015. We use daily closing mid-prices of German government bonds, obtained from Bloomberg, to calculate yield-to-maturity following market conventions. German Federal bonds (Bunds), five-year Federal notes (Bobls), and Federal treasury notes (Schätze) are listed on the German stock exchanges which provides transparency about daily prices and yields (Deutsche Bundesbank, 2016). ${ }^{8}$ We complement the daily yield data with bond characteristics, such as issue and maturity dates and information on coupon and issuance amounts from Bloomberg. We also collect data from the German Finance Agency (Finanzagentur $\mathrm{GmbH}$ ) on all primary auctions during our sample period, including information on issuance amounts, initial average and lowest prices, average yields and bid-tocover ratios. To adjust for market liquidity and demand for a security, we also create an on-

\footnotetext{
${ }^{8}$ Despite excluding government bills due to differences in market conventions and microstructure, our bond sample covers $70 \%$ flow and $90 \%$ stock of German sovereign debt.
} 
the-run dummy, capturing the liquidity premium in secondary market yields, as in Krishnamurthy (2002) and Jordan and Jordan (1997).

Using International Securities Identification Numbers (ISIN), we match bond yields and bond characteristics from Bloomberg and the Finanzagentur primary market data with securities lending market data from IHS Markit. In the merged dataset, we have information on the total supply value and total borrowing value in USD. ${ }^{9}$ In the empirical analysis, we use the natural logarithm of the total supply and demand values in millions of EUR (LogSupply and $\log$ Demand), converted from the USD values provided by IHS Markit using the daily official exchange rates from the Statistical Warehouse of the ECB.

In addition to demand and supply variables, we also use the utilization rate (Utilization), which is the percentage of the total supply that is currently lent out. The other key measures are related to the lending income. We use the average lending fee, the annualized valueweighted average lending fee (Allfees) that is based on all outstanding contracts for a given ISIN, measured in basis points. Since the variable is highly skewed (which is welldocumented in the literature, e.g., Duong et al., 2018; Gagnon, 2018), in the empirical analysis, we use the natural logarithm of the value-fees (LogFees). Last, we also apply the Feespread measure, which is the difference between the highest and lowest fee in basis points on all outstanding contracts for a given ISIN on a given day.

IHS Markit also provides information on total return on securities lending, which is expected to also capture the reinvestment income. The reinvestment income, the alternative sources of revenue from securities lending is discretionary, depends on the beneficial owner and agents' agreement. In recent years lenders increasingly focus on the fee component (SLT,

\footnotetext{
${ }^{9}$ While the equity focused securities lending studies use relative measures, scaling with the total shares outstanding, we are forced to rely on aggregate nominal values because the total outstanding bond volume or value information is unavailable on the daily basis. At any point in time, in the secondary sovereign bond market, it is difficult to measure the exact available total quantity because of ongoing central bank interventions.
} 
2010). The fee measure is an outcome of negotiation not based on market condition or the success of re-hypothecation; thus, it is the true measure of the lenders bargaining power and is most suitable to address our research question.

\subsection{Summary Statistics}

Table 1 presents the summary statistics of the key variables based on our sample of German nominal bonds for the period of July 2006 to June 2015. Table 1 shows that in our sample the average bond has an issue size of EUR 17.5 billion, it was issued about 5.5 years ago (Age) and has 7.8 years remaining until maturity $(T T M)$. The average coupon rate is $3.57 \%$, while yield-to-maturity is $1.99 \%$. On average, $5.1 \%$ of the outstanding bonds are on-the-run. Considering the securities lending market activity measures, during our sample period, the average total supply is about $€ 3.7$ billion (Suppleurval) per issue with average total demand of 2.3 billion (Demandeurval). The average lending fee (Allfees) is 10.8 bps with an average spread (Feespread) of 3.83 bps. The average utilization rate (Utilization) is $51.6 \%$. The latter high utilization rate, striking in comparison with the equity market, signals the importance of the securities lending activity for safe and liquid fixed income securities.

[Table 1 about here]

In the lower section of Table 1, we provide summary statistics for bonds with 10 years or longer maturity. ${ }^{10}$ As suggested by the 2015 BIS study, these longer term assets are more likely to be held by pension funds and insurance firms. While these assets facilitate risk management by minimizing the maturity gap of assets and liabilities, their compensation for duration risk and higher coupons help with income generation. About 1/4 of our sample is in the longer maturity segment, with an average coupon rate of 5\% and TTM about 21.5 years. Interestingly, the securities lending market variables are comparable across the two samples.

\footnotetext{
${ }^{10}$ While we do not report all summary statistics for all maturity buckets in the main text, additional subsample statistics are available upon request.
} 
The average fee is about $11.6 \mathrm{bps}$, while the supply value is somewhat larger, about $€ 4.4$ billion in comparison with the $€ 3.7$ billion in the full sample, the demand value is slightly lower, about $€ 1.6$ billion in comparison with $€ 2.3$ billion in the full sample.

In addition to pooled panel summary statistics in Table 1, we also provide time-series insights in Figure 2, which depicts the moving monthly averages of the key variables. The upper panel depicts the average of value-weighted fees and the utilization rates over time. The average fee shows significant variation over time, with a notable increase after the Lehman bankruptcy in 2008, and a peak at around 40 bps at the height of the European debt crisis. Specifically, the average fee rose substantially in the fall of 2011, spiking at 25 bps in November, just before the ECB implemented the largest ever infusion of credit into the European banking system, providing €489 billion in loans to 523 banks (Reuters, 2011).

[Figure 2 about here]

\subsection{Hypothesis Development}

While regulators are optimistic about the effect of the QE, the welfare implications of a decade of near zero interest rates are far from clear. On the one hand, investors, who invested directly in the European or U.S. stock markets could have almost doubled their investment by trading major U.S. index (e.g., S\&P500 trackers) or trading on the German Stock Exchange index (e.g., DAX trackers) between January 2010 to July 2015 (see Figure 3 for reference).

[Figure 3 about here]

On the other hand, investors of fixed income securities, by and large, missed out on this market run-up. During the same period, the annualized return on the safe long-term sovereign bond, such as long-term German Bunds, was only about 2\% on average. Part of the reason why yields have become so low on safe and liquid assets is a result of regulatory efforts focused on systemically relevant institutions and trading that were implemented to prevent future crises. In reaction to the stricter capital reserve and the new liquidity requirements, 
banks started piling up cash and liquidity, especially around reporting dates. In addition, the push to central clearing increased the global demand for collateralizable assets. ${ }^{11}$ This gave rise to a shortage of HQLA, which in turn pushed interest rates below zero on the safest Eurozone sovereign bonds.

A large fraction of the long-term safe German sovereign bonds are held by regulated government and public pension funds and insurance firms, who are responsible for supporting the average old age citizen in most European countries. The extremely low interest rate environment after 2010 likely benefitted pension funds and insurers from a valuation perspective. Effectively, the increased paper valuation of the exiting large bond holding improved their coverage ratios, while not affecting liability valuation and discount rates. Nevertheless, the extreme high demand for HQLA likely put pressure on ongoing operations, where the acquisition of new assets have become increasingly expensive and potentially difficult.

In this study, we are concerned with the welfare implication of the new regulatory efforts and the prolonged expansionary monetary policy in conjunction with securities lending market activity. Our empirical hypotheses build on the life-cycle of safe treasury investments and the potentially misaligned interests between prime brokers and wealth preservation agents. We specifically focus on pension funds, as these entities are large passive investors of safe government bonds, where auxiliary income from securities lending can play a significant role. We assume that these conservative investors are the de facto beneficial owners in the longer maturity segment, as they are likely to invest in longer term treasuries for higher yields and to minimize the duration gap between their assets and liabilities. ${ }^{12}$

\footnotetext{
11 The demand for HQLA is expected to reach \$4 trillion by 2020 (Oliver Wyman, 2013), suggesting a large potential shortfall (Singh, 2013; Aggarwal et al. 2016).

${ }_{12}$ According to the 2015 BIS report, the average duration of insurance firms holdings is above 10 years, while the average German pension duration is about 22 years across men and women in 2016, suggesting that the
} 
In Figure 4, we depict the three stages of the life-cycle of treasury investments from a pension fund's perspective and show that prime broker-agents have an integral role both in the purchase, as well as in the long-term holding process. Our two empirical hypotheses concern market frictions and conflict of interest issues between beneficial owners and prime brokers-agents. In Stage 1, government bonds are directly auctioned to a small group of primary dealers, many of whom are prime brokers and also active agents in securities lending. With our first hypothesis we test whether prime dealers are influenced by the securities lending market demand in their price formation process in the primary market by examine whether the demand is expected to be captured in future securities lending income that fully compensates beneficial owners. Specifically, we formulate the following hypothesis:

$H 1$ (null): The interest of primary dealers that emanates from the future securities lending demand is fully priced in at the initial bond auction in the form of expected future lending income.

$H 1$ (alternative): The additional interest of primary dealers that emanates from the future securities lending demand is priced in in access of the expected future lending income.

The bidding agents (e.g., investment banks) might have an inherent interest in bidding for HQLAs to fulfil capital reserve requirements, or because they know that these assets are in shortage in the secondary market, or they can be important in maintaining banking relationships with key asset management firms to facilitate collateral swaps. Conflict of interest is likely to arise in selling HQLAs to pension funds because the dealer banks know that by selling "special" assets to pension funds or insurance firms, they can later secure 
access to these assets by acting as their lending agent. The empirical question is whether the market is fully efficient to compensate beneficial owners for the "specialness" of their HQLA holdings through future securities lending transactions, or whether prime brokers exploit their information advantage and underrepresent the interest of pension funds.

To further explore whether passive beneficial owners' interests are well represented in the opaque securities lending market, we test whether long-term conservative investors with buy and hold strategies, holding large safe bond portfolios, are able to actively realize material income from securities lending. While our null hypothesis is that in a well-developed, competitive securities lending market prices (lending fees) dynamically capture demand and supply, the alternative hypothesis stems from market inefficiencies and the agency conflict between agents and beneficial owners. During our sample period, the high demand for HQLAs, (e.g., German sovereign bonds) would create market conditions, where the demand and supply shocks are more likely to be priced in, as suggested by (Kolasinski et al., 2013) in the equity context.

Thus, our empirical test is biased against us and if we find that demand pressure does not translate to higher lending income on the sale side, then we provide support for market inefficiencies and agency conflicts. These issues are likely to be exacerbated in the long maturity segment, where beneficial owners (lenders) are passive long-term investors, who generally do not manage active lending desks and might be unaware of the demand and supply forces in the securities lending market. This makes them vulnerable to be "exploited" by prime brokers, who underrepresent their interest by giving them a smaller cut from the lending fee.

H2 (null): In a well-functioning securities lending market with rational expectations, lending fees should instantaneously incorporate expected and realized demand pressures. 
H2 (alternative): In an inefficient securities lending market, fees react to changes in demand with delay; and not all lenders are equally compensated.

We examine the market reaction to both realized and expected demand and supply changes. Unlike the extant empirical studies examining the efficiency of the equity securities lending market, which focus only on the fee elasticity in conjunction with endogenous demand and supply changes, we are also able to consider exogenous demand and supply effects in addition to endogenous changes. In efficient markets, securities lending should not only capture the ex post demand pressure but also incorporate changes in the expected demand or supply.

More importantly, we also attempt to address lender heterogeneity. We examine the primary hypothesis not only in the full sample, but in the subsample of long maturity bonds, where most beneficial owners and thus the ultimate lenders are pension funds and insurance firms. If prime brokers and dealers withhold information or exercise their market power, these less connected lenders may be less effective to capitalize on demand pressures, as suggested by Duffie et al. (2002; 2005) and Chague et al. (2017) in the context of equity lending. In addition, in this subsample, the welfare implications are more pronounced and should attract regulatory attention.

\section{Empirical Analysis}

In Section 4.1., we test our Hypothesis 1, whether the primary auction demand effectively captures the expected realizable lending income and discuss the arising agency conflicts between the prime broker-agents and the longer term conservative treasury investor, the future beneficial owner-lender in the securities lending market. Second, in Sections 4.2 and 4.3 we provide insights into the overall time trend in German treasury yields during our sample period from 2006 to 2015, and study the influence of securities lending market 
demand on secondary market prices to show that the securities lending market from the beneficial owners' perspective may function inefficiently if beneficial owners have limited bargaining power, as suggested by Duffie et al. (2002; 2005).

\subsection{Securities Lending Market Implications in the Primary Auction Market}

To understand the pricing implications of the securities lending market from a long-term investor's perspective, it is imperative to start at the auction process in which the initial bond prices are formed, and the prime broker-bidding agent secures the asset from the Debt Management Office or Treasury, such as the Finanzagentur for German nominal treasury bonds. For the auction process, we collect data from the Finanzagentur. The dataset contains coupon rate, tenor, issue size, average price and yield, expected issue size, and bid-to-cover ratios. The relevant summary statistics based on the 296 unique new issuances and reopenings in our sample are presented in Table 3.

[Table 3 about here]

The upper section of Table 3 presents statistics of the overall auction sample for the period of July 2006 to June 2015. We include both new issuances and reopenings $(70 \%$ of the sample), where multiple reissuances allow a specific ISIN target volume to be reached. The value-weighted average prices are slightly above the face value, which also translates into often negative yields in periods of HQLA demand pressure and flights to safety. The average auction has a bid-to-cover (BTC) ratio of 1.66, while oversubscription (BTC $>2$ ) for issues is quite common, suggesting the string supply for the Eurozone benchmark asset. Coupons range from $1.96 \%$ to $4.75 \%$, and are somewhat higher in the subsample issues with longer than 10-year remaining tenure.

We construct securities lending benchmarks for all issuances, specifically for fees (BenchFee), utilization (BenchUti) and also for yields (BenchYield). These variables are defined as 10-day moving averages for a specific securities lending measure in a specific 
maturity segment similar for both newly issued and reopened bonds. For instance, when we calculate the BenchFee for a newly issued 5-year bond, we take the pooled average of the individual 10-day moving average fees for each outstanding, already traded bonds in the 5-10 year maturity bucket.

The average benchmark fee is 9.5 bps while the average benchmark utilization rate is around $53 \%$. In the lower section of Table 3, we present the summary statistics of new issues with a maturity of 10 years or longer. In this subsample, most features are qualitatively similar, with yields and coupons being higher to compensate for duration risk and the term premium. We also create two new measures, RelImp and Interest. RelImp captures the relative importance of the specific bond issue in the securities lending market, measured as the new issue size relative to the total outstanding supply in a specific maturity bucket. Interest measures the primary dealers' interest for the specific issue as the ratio of competitive to non-competitive bids submitted at the initial auction.

In Table 4, we test the pricing implications of the HQLA excess demand and the expected securities lending income. Specifically, in Table 4, the significant negative coefficient in Models 4 and 6 on benchmark fees suggest that lending fees are priced in at the initial auction. More importantly, we find that the primary dealers' interest is an additional important yield predictor, as more competitive bids, capturing increased dealer interest, is associated with significantly lower yields. The significant negative coefficient on the benchmark utilization measure also indicates that higher expected lending income is priced in and investors are willing to accept lower yields, while the positive coefficient on the interaction variable of BenchUti*Interest indicates some endogeneity between the two measures.

[Table 4 and 5 about here] 
In Table 5, we address the endogeneity of the Interest variable by running a two-stage instrumental variable regression, in which we use bond characteristics and securities lending market information to proxy for the competitive bidding interest. We show that primary dealers' interest captures various aspects of a bond issue, including the issue size, the maturity segment and whether the auction is a reopening or a new issuance. Larger issue size and longer maturity bonds, on average, attract higher interest, but the negative coefficient on the interaction term (LogSize ${ }^{*}$ Longmat) suggests a more complex relation. More importantly, the relative importance (RelImp) of the issue is the key determinant of the competitive bidding interest. The large significant positive coefficient on RelImp implies that brokers specifically target issues, which are likely to become important in the securities lending market, or for the banks' clients.

These inferences are robust to the inclusion of various securities lending income proxies from Models 2 to 4 . In the second stage, we see that our instrumented Interest variable is significant with a negative sign, indicating demand pressure from primary dealers that is priced in on top of the benchmark utilization and fee measures. These results suggest (albeit indirectly) that as primary dealers' interest is not aligned with that of the ultimate beneficial owners, long-term investors may have to buy safe assets at an inflated price, thereby reducing the wealth preservation and return generating potential of pension funds and insurance firms.

\subsection{Panel Regression Analysis of Daily German Treasury Yields in the Secondary Market}

In this section, we first document the downward trend in German sovereign bond yields after 2010, as a by-product of the large scale purchase programs of central banks and the QE. In addition, we are interested in the pricing implications of the securities lending market. If the income from securities lending is material, the expected lending fees should be captured in secondary market prices (or yields), as suggested by Duffie et al. (2002). However if market 
demand is low, or lenders have limited bargaining power or representation by the agent lenders, the expected trivial lending income would not influence prices (yields).

[Table 6 about here]

The results in Table 6, Panel A show that higher securities lending market utilization rates are associated with lower yields, suggesting that investors are willing to pay higher secondary market prices for securities with higher realizable expected lending income. ${ }^{13} \mathrm{We}$ find similar results in Models 4 and 5, where we focus on securities lending demand and supply measures. We find that the higher the lending demand for a given security, the lower the yields (higher the prices) are.

In Table 6 Panel $\mathrm{B}$, we repeat the analysis including an additional dummy variable (Longmat) that takes on the value of one for bonds with more than 10 years to maturity. We also include an interaction of this dummy with the main securities lending variables. In Model 5, we find that utilization rates have a pronounced effect for long maturity bonds in addition to fees.

\subsection{Price Dynamics for German Treasuries in the Securities Lending Market}

To test our first hypothesis, in Table 7 we examine lending fee dynamics in the panel setting. Lending fees effectively proxy for the lending market liquidity of a specific bond, where the fees are established as the intersection of demand and supply. Higher fees imply that the owner of the security can earn some additional income, which is why beneficial owners may accept holding assets with lower yields (Duffie, 1996). In Table 7, we find significant positive coefficient on the demand change dummy variable DemIncrease ${ }_{t}$, which takes on the value of one when the lagged one day change in realized demand was greater than $2 \%$, an increase within the top quartile of the demand change distribution. More importantly, we find

\footnotetext{
${ }^{13}$ In Online Appendix B, we provide extended tables, displaying year fixed effects.
} 
that fees react to an increase in demand with some delay, thereby supporting our alternative hypothesis regarding securities lending market inefficiencies. Last, in Table 7, Models 4-6, we include the long maturity dummy (Longmat) and its interactions with the alternative DemIncrease $_{t}$ measure. We find that the pricing in of demand changes in the longer end of the yield curve is muted.

\section{[Table 7 about here]}

Next, in Table 8, we focus on exogenous demand shocks that are known to market participants in advance. ${ }^{14}$ The most prominent expected shocks are the cyclical demand pressures for HQLAs at year-end regulatory reporting dates and new issuances of comparable Treasuries, where dates are known in advance from the issuance calendar. In an efficient market, all public information should be fully captured in prices. Table 8 presents the relevant empirical results with the lending fee dynamics at year-end reporting dates.

[Table 8 about here]

Banks with large trading desks have traditionally been active participants of repo and securities lending markets. However, due to the increasingly stringent recent regulation and reporting requirements, banks are incentivized to lock in HQLA in their portfolios for yearend reporting dates to minimize their required capital buffers. Consequently, around these dates, nonbank lenders may be able to capitalize on their "unique" lender position (ICMA 2017).

In Table 8, we find that fees are significantly higher around year-end using five calendar days to proxy for year-end (Repwind). ${ }^{15}$ This result is robust to the inclusion of controls for contemporaneous and lagged supply and demand. In Table 8 Models 2 to 4 also incorporate

\footnotetext{
${ }^{14}$ Additional regression results are available for Tables 7 and 8 , where we find insignificant results based on fees. This suggests that lending supply changes do not have a major effect on fees.

${ }^{15}$ In auxiliary analyses, we use 3 and 4 calendar days, as well as 3, 4, and 5 trading days. The results are economically and statistically similar to the reported ones.
} 
the dummy Longmat for long maturity bonds. We find that at the long end of the yield curve, fees are less sensitive to the changes in expected demand shocks around year-end reporting dates. Models 3 and 4 also incorporate a dummy Aft2010 that takes the value of 1 in year 2010 and thereafter. This variable captures the fee increase following the inception of the European debt crisis, but its interactions with Repwind and Longmat show a mixed picture.

The fees seem to increase at the year-end after 2010, captured by the positive coefficient on the Aft2010*Repwind interaction variable in Model 3. However, once we include the triple interaction term Aft2010*Repwind*Longmat in Model 4, the coefficient on Aft2010*Repwind becomes less significant. This suggests an absence of a significant fee reaction in the natural habitat of long-term investors at year-ends even after 2010. In other words, while pension funds may have become more important as liquidity providers as lenders in the treasury market, they are not fully compensated. These results support our H2, suggesting that pension funds are in an adverse position due to the lack of strong bargaining power, and thus they are not able to fully realize the potential from securities lending. This finding is consistent with Duffie et al. (2005)'s theory.

[Table 9 about here]

In Table 9, we provide a more detailed test examining the heterogeneity in lending fees to provide more direct evidence of discriminative pricing behaviour by agents. Specifically, we examine the Feespread, the difference in the highest and lowest fees on all contracts on a specific date for a specific ISIN. Given the high utilization rates, beneficial owners should all benefit from high income. However, if insurance firms' and pension funds' interests are not well represented, we expect to find that while some lenders are able to capitalize on the high demand, others cannot. Indeed, the results from Table 9 show that with a higher utilization rate, the fee spread narrows on average. 
On the other hand, we see that Feespread increases with supply and around year-end reporting dates, confirming that not all lenders are able to capitalize on temporarily increased lending fees around reporting dates. Results from Models 6 and 7 show that with higher fees and higher demand the spread increases, which is in line with our hypothesis and suggests price discrimination in the market on the sale side, complementing the buy-side results of Kolasinski et al. (2012) and Chague et al. (2017). To further explore this issue, we focus on the role of conservative long-term investors by including the Longmat dummy variable and its interaction terms with utilization, fees and demand. We find that most coefficients are positive (albeit statistically insignificant in our small sample), suggesting that in the long maturity segment some less connected beneficial owners receive a persistently low fee income, while some special clients with greater bargaining power receive higher fees. This further confirms Hypothesis 2 that fees are not only slow to incorporate lending market information but they are also dependent on the market power and connectedness of lenders.

Taken together, the results from Tables 6-9 provide important evidence of market inefficiencies on the sale-side of the securities lending market. While the securities lending literature primarily focuses on buy-side borrower discrimination, we provide the first insights on the sell side of the fixed securities lending market with a focus on the beneficial owners' perspective. We present some evidence of price discrimination and suggest that prime brokeragents systematically underrepresent less connected lenders' interest in the non-transparent oligopolistic market.

\section{Conclusion}

In this study, we empirically examine the functioning of the securities lending market for German treasuries from July 2006 to June 2015 and find strong evidence of market inefficiency. We first show that in the primary market, prime broker bidding group members 
may artificially inflate the prices of HQLA in search of scarce safe assets, disadvantaging the long-term investors, such as pension funds, who have to gain access to these assets. More importantly, we show that in the securities lending market, prime brokers acting as lending agents for pension funds, can exploit their information advantage and do not fully compensate lenders, who have limited insights and low bargaining power.

Overall, we suggest that the inherent inefficiencies in the securities lending market have important negative welfare implications for the European pension system. Pension funds and insurance firms struggle to generate returns or alternative lending income from securities lending, while on the other hand, being responsible for preserving wealth and managing retirement savings for the majority of European citizens.

We suggest that long-term sovereign bond investors should become more active in the securities lending market because their interest may not be well-represented by the major prime broker-agents. Thus, we recommend that pension funds and insurance firms start lobbying for regulatory oversight and/or more transparency to reduce the documented inefficiencies. Alternatively, sovereign debt management offices or treasuries may want to consider granting direct access to long-term investors to the primary market, which currently is a common practice for instance in Singapore. This would allow pension funds to access safe assets without involving prime brokers, eliminating potential rent extraction between primary and secondary market transactions. 


\section{References}

Aggarwal, R., Bai, R., and Laeven, L. 2016. The Role of the Government Bond Lending Market in Collateral Transformation, Working Paper. Georgetown University.

Amery, P., 2008. More on Counterparty Risk (Securities Lending). IndexUniverse.com, October 20; available at http://www.indexuniverse.com/sections/features/4670-more-oncounterparty-risk-securitieslending.html?utm_source=newsletter\&utm_medium =email\&utm_campaign=IndustryNews.

Anderson, R. and Li, Y., 2013. How Low Can You Go? Negative Interest Rates and Investors' Flight to Safety, Regional Economist. Federal Reserve Bank of St Luis. Pages $1-13$.

Arnesen, J., 2017. Central Banks and Securities Lending: A Lever for Monetary Policy and Liquidity Management, 22/12/2017, http://securities.bnpparibas.com/insights/centralbanks-and-securities-len.html

Bloomberg, 2016. Bond Squeeze 'Bleeding to Death' \$28 Billion Pension Fund, by Mayes Joe, https://www.bloomberg.com/news/articles/2016-11-17/bond-squeeze-bleeding-todeath-28-billion-french-pension-fund

Boehmer, E. and Wu, J., 2013. Short Selling and the Price Discovery Process, The Review of Financial Studies 26 (2), 287-232.

CalPERS, 2009. CalPERS \& CalSTRS report lending losses. https://calpensions.com/2009/08/20/calpers-calstrs-reports-lending-losses/

Chague, F., De-Losso, R., De Genaro, A., and Giovannetti, B. 2017. Well-Connected ShortSellers Pay Lower Loan Fees: A Market-Wide Analysis, Journal of Financial Economics 123(3), 646-670. Deutsche Bundesbank, 2016. Prices and yields of listed Federal securities, Deutsche Bundesbank, Eurosystem, https://www.bundesbank.de/ 
Navigation/EN/Service/Federal_securities/Prices_and_yields/_prices_and_yields.html (accessed on October 28, 2016).

Duffie, D., 1996. Special Repo Rates. The Journal of Finance 51, 493-526.

Duffie, D., Gârleanu, N., and Pedersen, L. H., 2002. Securities Lending, Shorting, and Pricing. Journal of Financial Economics 66 (2-3), 307-339.

Duffie, D., Gârleanu, N., and Pedersen, L. H., 2005. Overt-The-Counter Markets, Econometrica 73 (6). 1815-1847.

ECB, 2014. Collateral Eligibility and Availability, Follow-up Report on "Collateral Eligibility Requirements - A Comparative Study across Specific Frameworks", https://www.ecb.europa.eu/pub/pdf/other/cea201407en.pdf?c5856909bbcb7b0ed884be5b2 $81 \mathrm{ddc} 24$

ECB, 2016. European Central Bank. Statistics on Euro Area Insurance Corporations and Pension Funds: Second Quarter 2016, Press Release, 30 September 2016, https://www.ecb.europa.eu/press/pdf/icpf/icpf16q2.pdf

ECB, 2017a. Asset Purchase Programs, $\underline{\text { https://www.ecb.europa.eu/ }}$ mopo/implement/omt/html/index.en.html

ECB, 2017b. Bond scarcity and the ECB's Asset Purchase Programme, Speech by Benoît Cœuré, Member of the Executive Board of the ECB, at the Club de Gestion Financière d'Associés en Finance, $\quad$ Paris, 3 April 2017, https://www.ecb.europa.eu/press/key/date/2017/html/sp170403_1.en.html

European Commission, 2018. Pension Adequacy Report: Current and Future Income Adequacy in Old Age in Europe, Volume 2: Country Profiles. doi:10.2767/653851

Financial Times, 2017a. How the ECB's Purchases Have Changed European Bond Markets, February 8, 2017 by Thomas Hale, https://www.ft.com/content/c5568324-ec8f-11e6-930f061b01e23655 
Financial Times, 2017b. What has the Bank of England's corporate bond buying achieved?, April 3, 2017. https://www.ft.com/content/be19fbb4-1623-11e7-80f4-13e067d5072c

Finanzagentur, 2015. Bund Issues Auction Group, Bundesrepublic Deutschland Finanzagentur, GmbH, http://www.deutsche-finanzagentur.de/en/institutionalinvestors/primary-market/bund-issues-auction-group/ (accessed September 25, 2015).

Gagnon, L. 2018. Short Sale Constraints and Single Stock Futures Introductions. The Financial Review 53, 5-50.

Gagnon, L. and J. Witmer, 2014. Distribution of Ownership, Short Sale Constraints, and Market Efficiency: Evidence from Cross-listed Stocks. Financial Management, 631670.

Global Pension Assets Study 2016, Willis Tower Watson, February 2, 2016. https://www.willistowerswatson.com/en-CH/insights/2016/02/global-pensions-assetstudy-2016.

ICMA, 2017. Closed For Business: A Post-Mortem of the European Repo Market BreakDown over the 2016 Year-End, by Andy Hill, February 2017, https://www.icmagroup.org/resources/icma-publications-and-services/icma-reports/

ICMA, 2018. What is the Difference between Repo and Securities Lending? https://www.icmagroup.org/Regulatory-Policy-and-Market-Practice/repo-and-collateralmarkets/icma-ercc-publications/frequently-asked-questions-on-repo/14-what-is-thedifference-between-repo-and-securities-lending/

IHS Markit, 2016. Securities Lending: A Year in Review. 21 December, 2016. http://www.markit.com/Commentary/Get/21122016-Equities-Securities-lending-year-inreview. 
IPE, 2016. Pensions in Germany: The Joys Of Negative Rates. Investment and Pensions Europe (IPE), April 2016. https://www.ipe.com/pensions/pensions-in/germany/pensionsin-germany-the-joys-of-negative-rates/10012506.fullarticle (Accessed March 9, 2017).

ISLA, 2016. Reports at the European Post Trade Forum, Brussels, May 2016, http://ec.europa.eu/finance/financial-markets/docs/clearing/eptf/160519-isla_en.pdf.

Jordan, B. D. and Jordan, S. D., 1997. Special Repo Rates: An Empirical Analysis. The Journal of Finance 52, 2051-2072.

JP Morgan, 2011. A Best Practice Oversight Approach for Securities Lending, JP Morgan Thoughts 2011, https://www.jpmorgan.com/cm/BlobServer/A_Best_Practice_Oversight_ Approach_for-Securities_Lending.pdf?blobkey=id\&blobwhere $=1320546654155 \&$ blobheader=application/ pdf\&blobheadername $1=$ CacheControl\&blobheadervalue $1=$ private $\&$ blobcol $=$ urldata\&blobtable $=$ MungoBlobs

Kolasinski, A., Reed, A., and Ringgenberg, M. C., 2013. A Multiple Lender Approach to Understanding Supply and Search in the Equity Lending Market. Journal of Finance 68, $559-595$.

Krishnamurthy, A., 2002. The Bond/Old Bond Spread. Journal of Financial Economics 66, $463-506$.

Mercer, 2014. Asset Allocation of Pension Funds around the World, Financial Services Council, 2014 February. http://fsi.gov.au/files/2014/04/Mercer_FSC_report.pdf

Oliver Wyman, BCBS / IOSCO QIS, 2013, Wholesale \& Investment Banking Outlook, Global Banking Fractures: The Implications, Blue paper, Morgan Stanley and Oliver Wyman Research, April 11, 2013. http://www.oliverwyman.com/content/dam/oliverwyman/global/en/files/archive/2013/Outlook_for_Wholesale_and_Investment_Banking_2 013.pdf

Portes R., 2010. Ban naked CDS. Eurointelligence, March 18 
Reuters, 2011. Exclusive: Italian Banks Tap 116 billion Euros of ECB loans, December 22, 2011. http://www.reuters.com/article/us-italy-banks-ecb/exclusive-italian-banks-tap-116billion-euros-of-ecb-loans-idUSTRE7BK1NL20111221

Reuters, 2017. U.S. Pension Funds Sue Goldman, JPMorgan, Others over Stock Lending Market, by Daniel Wiessner, Aug 18, 2017.https://www.reuters.com/article/usstocklending-lawsuit/u-s-pension-funds-sue-goldman-jpmorgan-others-over-stocklending-market-idUSKCN1AX2NK

Saffi, P. A. C. and Sigurdsson, K., 2011. Price Efficiency and Short Selling, Review of Financial Studies 24 (3): 821-852.

Singh, M., 2013. The Changing Collateral Space, IMF Research Paper.

SLT, 2010a. SGX bolsters SBL service. Securities Lending Times, Issue 10, October 5, 2010, http://www.securitieslendingtimes.com/sltimes/SLTimes_issue_10.pdf

SLT, 2010b. The right place, the right time by Greg DePetris. Securities Lending Times, Issue $\quad 10, \quad$ October $\quad 5, \quad 2010, \quad$ http://www.securitieslendingtimes.com /sltimes/SLTimes_issue_10.pdf

SLT, 2010c. First blood for Northern Turst in Diebold case, Chicago, 30/09/2010. Securities Lending Times, $\quad$ Issue $\quad 10, \quad$ October $\quad 5, \quad$ 2010, http://www.securitieslendingtimes.com/sltimes/SLTimes_issue_10.pdf

State Street 2016. The Savers Save Europe and Themselves. State Street Global Advisors. Official Institutional Group. August 2016.

WSJ, Bond Investors' Suit Claims Dealers Colluded on Treasury Prices, By Daniel Kruger Published November 16, 2017, https://www.wsj.com/articles/bond-investors-suit-claimsdealers-colluded-on-treasurys-prices1510873541?mod=cx_picks\&cx_navSource $=\mathrm{cx} \_$picks\&cx_tag $=$contextual $\& \mathrm{cx} \_$artPos $=2 \# \mathrm{cxrecs} \_\mathrm{s}$ 
Table 1. Description of Variables

\begin{tabular}{|c|c|}
\hline Variables & Definition and explanation \\
\hline Issue size (LogSize) & $\begin{array}{l}\text { Issue size is the total issue size in million euros, as reported by the German } \\
\text { Bundesbank at the time of issuance. }\end{array}$ \\
\hline Coupon & Coupon rate is the annual percentage amount, as reported by the Bundesbank. \\
\hline Ontherun & $\begin{array}{l}\text { Ontherun is an indicator variable. It takes the value of one for the days when the } \\
\text { specific security is on-the-run for its tenor, and is zero for all seasoned securities. }\end{array}$ \\
\hline Yield or YTM & $\begin{array}{l}\text { Yield-to-maturity is at the daily frequency and is calculated based on the daily closing } \\
\text { secondary market mid prices from Bloomberg, following market conventions. }\end{array}$ \\
\hline $\begin{array}{l}\text { Time-to-maturity } \\
\text { (TTM) and (Age) }\end{array}$ & $\begin{array}{l}\text { TTM is the time-to-maturity of specific Germany treasury, measured in years and with } \\
\text { a 2-digit accuracy. Age is the number of years since issuance, at the 2-digit accuracy. }\end{array}$ \\
\hline Allfees & $\begin{array}{l}\text { Allfees is the value-weighted average annualized lending fee, based on all outstanding } \\
\text { contracts, as provided by the IHS Markit. The variable is reported in basis points. }\end{array}$ \\
\hline RelSupply & $\begin{array}{l}\text { RelSupply is the percentage of the total issuance volume available for borrowing. It is } \\
\text { calculated as the total available supply relative to the total issuance value, as reported } \\
\text { by HIS Markit. Since they report the daily lent out value in USD, we convert this value } \\
\text { into EUR, using the daily exchange rates from the Statistical Warehouse of the ECB. }\end{array}$ \\
\hline Utilization & $\begin{array}{l}\text { Utilization is the percentage value of assets on loan from lenders, divided by the total } \\
\text { lendable value. }\end{array}$ \\
\hline Feespread & $\begin{array}{l}\text { Feespread is the difference between the highest and the lowest fees on all outstanding } \\
\text { borrowing contracts for a specific security, on a given day. }\end{array}$ \\
\hline AvgPrice & $\begin{array}{l}\text { AvgPrice is the value weighted-average price at the initial auction, as reported by the } \\
\text { Finanzagentur. The price, following international conventions, is based on a } € 100 \\
\text { notional amount, or the percentage of the bond face value. }\end{array}$ \\
\hline AvgYield & $\begin{array}{l}\text { AvgYield is the value weighted-average yield, derived from the AvgPrice placed at the } \\
\text { initial auction, as reported by the Finanzagentur. }\end{array}$ \\
\hline Interest & $\begin{array}{l}\text { Interest measures the primary dealers' interest for the specific issue as the ratio of } \\
\text { competitive to non-competitive bids submitted at the initial auction. }\end{array}$ \\
\hline RelImp & $\begin{array}{l}\text { RelImp captures the relative importance of the specific bond issue in the securities } \\
\text { lending market, measured as the new issue size relative to the total outstanding supply } \\
\text { in a specific maturity bucket. }\end{array}$ \\
\hline BenchFee & $\begin{array}{l}\text { BenchFee is the average fee, based on the last } 10 \text { trading-day data of similar securities, } \\
\text { which are bonds within the same maturity bucket as the new issuance, and with the } \\
\text { same coupon rate. Our maturity buckets are } 0-1 \text { year, } 1-2 \text { years, } 2-5 \text { years, } 5-10 \text { years } \\
\text { and above } 10 \text { years. }\end{array}$ \\
\hline BenchUti & $\begin{array}{l}\text { BenchUti is the average utilization rate across bonds with the same maturity bucket as } \\
\text { the new issuance, based on the last } 10 \text { trading-day data, where the maturity buckets are } \\
0-1 \text { year, } 1-2 \text { years, } 2-5 \text { years, } 5-10 \text { years and above } 10 \text { years. }\end{array}$ \\
\hline
\end{tabular}




\section{Table 2. Summary Statistics of Daily Panel Data of German Nominal Treasury Secondary Market Data}

The table reports summary statistics of the main variables used in the empirical analysis, where the sample contains German nominal treasury securities lending market information based on IHS Markit data from July 3, 2006 to June 1, 2015. Age is the fraction of years since the first issue date, TTM is the time-to-maturity of a specific Germany treasury bond, both measured in years with 2-decimal accuracy. Coupon is the annual coupon rate in percentage format. Ontherun dummy takes on the value of one for a specific security for a given trading day, when the security is on-the-run for its tenor. Sizeineuro is the issue size in million euros. Yield is the daily yield-to-maturity and is calculated based on the daily closing mid prices from Bloomberg, following market conventions. AllFees is the annualized value-weighted average fee in percentage (in calculations we use the originally reported values in basis points). Feespread is the difference between the highest and lowest fees in basis points on all outstanding borrowing contracts for a specific security and trading day. Suppleurval is the total supply of a specific issue in millions of euro, while the RelSupply is the percentage of the total issuance volume available for borrowing. Utilization is the percentage of the total supply of the issue utilized, currently out on loan. For these measures, the numerator is the total available value and lent out value reported from Markit in USD, which is converted into EUR using the daily exchange rate from the Statistical Data Warehouse of the ECB.

\begin{tabular}{|c|c|c|c|c|c|}
\hline Label & $\mathbf{N}$ & Mean & Std. Dev & Minimum & Maximum \\
\hline \multicolumn{6}{|l|}{ Full Sample } \\
\hline Age & 115611 & 5.475 & 5.628 & 0.000 & 28.970 \\
\hline TTM & 115611 & 7.779 & 8.025 & 0.500 & 32.480 \\
\hline Coupon & 115611 & 3.566 & 1.620 & 0.000 & 6.500 \\
\hline Ontherun & 115611 & 0.051 & 0.219 & 0.000 & 1.000 \\
\hline Sizeineuro & 115611 & 17472.900 & 5107.939 & 750.000 & 27000.000 \\
\hline Yield & 115574 & 1.986 & 1.547 & -0.300 & 4.900 \\
\hline AllFees & 115611 & 0.108 & 0.122 & -0.663 & 4.172 \\
\hline Feespread & 104505 & 3.834 & 1.047 & -6.908 & 8.161 \\
\hline Suppleurval & 115611 & 3697.902 & 2695.570 & 0.000 & 35164.830 \\
\hline Demandeurval & 115611 & 2334.356 & 2116.582 & 0.000 & 15640.650 \\
\hline Utilization & 115611 & 0.516 & 0.243 & 0.000 & 1.000 \\
\hline \multicolumn{6}{|c|}{ Bonds with TTM $>10$ years } \\
\hline Age & 24572 & 9.003 & 5.068 & 0.000 & 20.020 \\
\hline TTM & 24572 & 21.507 & 5.965 & 10.010 & 32.480 \\
\hline Coupon & 24572 & 5.005 & 1.114 & 0.500 & 6.500 \\
\hline Ontherun & 24572 & 0.092 & 0.289 & 0.000 & 1.000 \\
\hline Sizeineuro & 24572 & 14730.760 & 4251.487 & 750.000 & 24000.000 \\
\hline Yield & 24554 & 3.029 & 1.121 & 0.100 & 4.900 \\
\hline AllFees & 24572 & 0.116 & 0.135 & -0.613 & 2.650 \\
\hline Feespread & 22012 & 3.957 & 1.039 & -2.3026 & 8.160 \\
\hline Suppleurval & 24572 & 4414.363 & 3063.018 & 0.000 & 21506.620 \\
\hline Demandeurval & 24572 & 1677.4579 & 664.67491 & 0.000 & 21506.620 \\
\hline Utilization & 24572 & 0.380 & 0.217 & 0.000 & 1.000 \\
\hline
\end{tabular}


The table reports summary statistics for German treasury auctions from July 6, 2006 to June 1, 2015. AvgPrice is the value weighted-average accepted bid price at the initial auction, as reported by the Finanzagentur based on $€ 100$ notional amount. Bid-to-cover ratio is the ratio of total bid value to the overall issued amount. AvgYield is derived from AvgPrice, as reported by the German Finanzagentur. Coupon rate is (Coupon) is the percentage annual coupon, while age is measured as the natural logarithm of the number until the maturity date $(\log A g e)$. Longmat and Reopening are dummy variables, which take the value of one, when the bond has more than 10 years remaining maturity, or when the issue is a reopening, respectively. BenchFee is the average fee based on the last 10 trading-day data of similar securities, which are bonds within the same maturity bucket as the new issuance and with the same coupon rate. Following the same logic, we define BenchUti and BenchYield as the average utilization rate and yield based on the last 10 trading-day data of similar securities, respectively. RelImp is the ratio of the bond issue size relative to the total supply in the same maturity bucket in the securities lending market. Interest is the fraction of the competitive bid and non-competitive bids in the auction process, while LogSize is the natural logarithm of the issue size recorded in millions of Euro. Benchmarks are based on the following maturity buckets: 0-1 year, 1-2 years, 2-5years, 5-10 years, and above 10 years.

\begin{tabular}{|c|c|c|c|c|c|}
\hline & $\mathbf{N}$ & Mean & Std. Dev & Minimum & Maximum \\
\hline \multicolumn{6}{|l|}{ Full Sample } \\
\hline AvgPrice & 296 & 100.761 & 4.053 & 87.920 & 138.250 \\
\hline Bid-to-cover & 296 & 1.663 & 0.387 & 1.000 & 4.000 \\
\hline AvgYield & 296 & 1.906 & 1.453 & -0.280 & 4.910 \\
\hline Coupon & 296 & 1.965 & 1.437 & 0.000 & 4.750 \\
\hline LogAge & 296 & 1.682 & 0.850 & 0.693 & 3.401 \\
\hline Longmat & 296 & 0.392 & 0.489 & 0.000 & 1.000 \\
\hline Reopening & 296 & 0.699 & 0.459 & 0.000 & 1.000 \\
\hline BenchFee & 296 & 0.095 & 0.042 & 0.007 & 0.249 \\
\hline BenchUti & 296 & 53.408 & 11.290 & 20.279 & 75.605 \\
\hline BenchYield & 296 & 1.694 & 1.460 & -0.235 & 4.779 \\
\hline RelImp & 296 & 0.159 & 0.111 & 0.033 & 0.791 \\
\hline Interest & 296 & 1.467 & 0.897 & 0.248 & 6.279 \\
\hline LogSize & 296 & 8.503 & 0.306 & 7.601 & 9.105 \\
\hline \multicolumn{6}{|c|}{ Bonds with TTM $>10$ years } \\
\hline AvgPrice & 116 & 101.781 & 6.233 & 87.920 & 138.250 \\
\hline Bid-to-cover & 116 & 1.504 & 0.322 & 1.100 & 2.700 \\
\hline AvgYield & 116 & 2.578 & 1.176 & 0.130 & 4.910 \\
\hline Coupon & 116 & 2.681 & 1.120 & 0.500 & 4.750 \\
\hline LogAge & 116 & 2.568 & 0.472 & 2.303 & 3.401 \\
\hline Reopening & 116 & 0.759 & 0.430 & 0.000 & 1.000 \\
\hline BenchFee & 116 & 0.099 & 0.042 & 0.025 & 0.212 \\
\hline BenchUti & 116 & 49.510 & 13.498 & 20.279 & 69.255 \\
\hline BenchYield & 116 & 2.283 & 1.269 & 0.007 & 4.779 \\
\hline RelImp & 116 & 0.104 & 0.056 & 0.033 & 0.306 \\
\hline Interest & 116 & 1.252 & 0.863 & 0.248 & 6.279 \\
\hline LogSize & 116 & 8.396 & 0.370 & 7.601 & 8.987 \\
\hline
\end{tabular}




\section{Table 4. The Pricing Implications of Expected Income from Securities Lending in the Primary Market}

The dependent variable is the primary auction day average yield outcome (AvgYield) in percentage. The explanatory variables are standard bond characteristics, such as the natural logarithm of the bond issue age defined as the number of years remaining until maturity $(\log A g e)$, and the coupon rate in percentage (Coupon). LogSize is the natural logarithm of the issue size recorded in millions of Euro. Reopening dummy variable takes on the value of one when the issue is a reopening. Interest is the fraction of the competitive bid and noncompetitive bids placed at the auction. BenchFee (BenchUti) is the average value weighted fee in basis points (utilization rate) based on the last 10 trading-day data of similar securities, which are bonds within the same maturity bucket as the new issuance. BenchUti*Interest is an interaction variable of the benchmark utilization rate and the Interest variables. The sample contains Germany nominal treasury securities lending market information based on IHS Markit data from July 2006 to June 2015. Coefficient estimates, reported from cross sectional regression, including year fixed effect and robust clustered standard errors at the year level, are reported with t-stats (in parenthesis). $* * *, * *$, and $*$ denote the $1 \%, 5 \%$ and $10 \%$ significance levels.

\begin{tabular}{|c|c|c|c|c|c|c|}
\hline & $\begin{array}{c}\text { (1) } \\
\text { AvgYield }\end{array}$ & $\begin{array}{c}(2) \\
\text { AvgYield } \\
\end{array}$ & $\begin{array}{c}(3) \\
\text { AvgYield }\end{array}$ & $\begin{array}{c}(4) \\
\text { AvgYield }\end{array}$ & $\begin{array}{c}(5) \\
\text { AvgYield } \\
\end{array}$ & $\begin{array}{c}\text { (6) } \\
\text { AvgYield }\end{array}$ \\
\hline Interest & $\begin{array}{l}-0.015 \\
(-0.67)\end{array}$ & $\begin{array}{l}-0.015 \\
(-0.69)\end{array}$ & $\begin{array}{c}-0.154 * * \\
(-3.02)\end{array}$ & $\begin{array}{c}-0.164 * * * \\
(-4.09)\end{array}$ & $\begin{array}{c}-0.150 * * \\
(-2.55)\end{array}$ & $\begin{array}{c}-0.158 * * * \\
(-3.26)\end{array}$ \\
\hline BenchUti & & $\begin{array}{l}0.043 \\
(0.19)\end{array}$ & $\begin{array}{c}-0.340 * \\
(-2.16)\end{array}$ & $\begin{array}{c}-0.389 * * \\
(-2.60)\end{array}$ & $\begin{array}{l}-0.264 \\
(-1.61)\end{array}$ & $\begin{array}{c}-0.286^{*} \\
(-1.91)\end{array}$ \\
\hline BenchUti*Interest & & & $\begin{array}{c}0.255^{* *} \\
(2.59)\end{array}$ & $\begin{array}{c}0.289 * * * \\
(3.63)\end{array}$ & $\begin{array}{c}0.245^{*} \\
(2.17)\end{array}$ & $\begin{array}{c}0.278 * * \\
(2.93)\end{array}$ \\
\hline BenchFee & & & & $\begin{array}{c}-0.273 * * \\
(-2.53)\end{array}$ & & $\begin{array}{c}-0.290 * * \\
(-2.82)\end{array}$ \\
\hline Longmat & & & & & $\begin{array}{c}0.106^{*} \\
(1.96)\end{array}$ & $\begin{array}{c}0.148 * * * \\
(3.76)\end{array}$ \\
\hline LogAge & $\begin{array}{c}0.165 * * \\
(2.72)\end{array}$ & $\begin{array}{c}0.165^{* *} \\
(2.68)\end{array}$ & $\begin{array}{c}0.160 * * \\
(2.77)\end{array}$ & $\begin{array}{c}0.189 * * \\
(2.67)\end{array}$ & $\begin{array}{l}0.105 \\
(1.46)\end{array}$ & $\begin{array}{l}0.114 \\
(1.60)\end{array}$ \\
\hline Coupon & $\begin{array}{c}0.750 * * * \\
(16.34)\end{array}$ & $\begin{array}{c}0.751 * * * \\
(15.88)\end{array}$ & $\begin{array}{c}0.758 * * * \\
(17.05)\end{array}$ & $\begin{array}{c}0.728 * * * \\
(12.26)\end{array}$ & $\begin{array}{c}0.749 * * * \\
(18.21)\end{array}$ & $\begin{array}{c}0.714 * * * \\
(13.09)\end{array}$ \\
\hline LogSize & $\begin{array}{l}0.096 \\
(0.65)\end{array}$ & $\begin{array}{l}0.089 \\
(0.53)\end{array}$ & $\begin{array}{l}0.096 \\
(0.58)\end{array}$ & $\begin{array}{l}0.073 \\
(0.49)\end{array}$ & $\begin{array}{l}0.014 \\
(0.08)\end{array}$ & $\begin{array}{l}-0.044 \\
(-0.28)\end{array}$ \\
\hline Reopening & $\begin{array}{l}-0.044 \\
(-1.55)\end{array}$ & $\begin{array}{l}-0.045 \\
(-1.63)\end{array}$ & $\begin{array}{l}-0.048 \\
(-1.69)\end{array}$ & $\begin{array}{l}-0.062 \\
(-1.81)\end{array}$ & $\begin{array}{l}-0.061 * \\
(-2.14)\end{array}$ & $\begin{array}{c}-0.081 * * \\
(-2.38)\end{array}$ \\
\hline Constant & $\begin{array}{l}-0.611 \\
(-0.49)\end{array}$ & $\begin{array}{l}-0.569 \\
(-0.42)\end{array}$ & $\begin{array}{l}-0.424 \\
(-0.31)\end{array}$ & $\begin{array}{l}0.427 \\
(0.33)\end{array}$ & $\begin{array}{l}0.312 \\
(0.22)\end{array}$ & $\begin{array}{l}1.509 \\
(1.15)\end{array}$ \\
\hline Time FE & Yes & Yes & Yes & Yes & Yes & Yes \\
\hline Observations & 296 & 296 & 296 & 296 & 296 & 296 \\
\hline R-squared & 0.972 & 0.972 & 0.973 & 0.975 & 0.973 & 0.976 \\
\hline
\end{tabular}




\section{Table 5. The Pricing Implications Excessive Bidding in the Primary Market}

The dependent variable is the primary auction day average yield outcome (AvgYield) in percentage from two stage regressions, where the endogenous variable, the brokers' interest (Interest) is instrumented by securities lending market variables. size (LogSize), age (Longmat) and the importance of the issue (Relimp). The explanatory variables are the same as in Table 7, in addition to relative importance and the dummy Aft2010, which takes on the value of one for year 2011 and thereafter. RelImp is the ratio of the bond issue size relative to the total supply in the same maturity bucket in the securities lending market. Interest is the fraction of the competitive bid and non-competitive bids in the auction process. LogSize ${ }^{*}$ Longmat is an interaction variable of the size of an issue, LogSize and indicator variable for ling maturities (Longmat). The sample contains Germany nominal treasury securities lending market information based on IHS Markit data from July 2006 to June 2015. Coefficient estimates, reported from cross sectional instrumental variable regressions with robust clustered standard errors at the year, are reported with t-stats (in parenthesis). $* * *, * *$, and $*$ denote the $1 \%, 5 \%$ and $10 \%$ significance levels.

\begin{tabular}{|c|c|c|c|c|c|c|c|c|}
\hline & \multicolumn{2}{|c|}{ (1) } & \multicolumn{2}{|c|}{ (2) } & \multicolumn{2}{|c|}{ (3) } & \multicolumn{2}{|c|}{ (4) } \\
\hline & $\begin{array}{l}1^{\text {st }} \text { Stage } \\
\text { Interest }\end{array}$ & $\begin{array}{l}2^{\text {nd }} \text { Stage } \\
\text { AvgYield }\end{array}$ & $\begin{array}{l}1^{\text {st }} \text { Stage } \\
\text { Interest }\end{array}$ & $\begin{array}{l}2^{\text {nd }} \text { Stage } \\
\text { AvgYield }\end{array}$ & $\begin{array}{l}1^{\text {st }} \text { Stage } \\
\text { Interest }\end{array}$ & $\begin{array}{l}2^{\text {nd }} \text { Stage } \\
\text { AvgYield }\end{array}$ & $\begin{array}{l}1^{\text {st }} \text { Stage } \\
\text { Interest }\end{array}$ & $\begin{array}{l}2^{\text {nd }} \text { Stage } \\
\text { AvgYield }\end{array}$ \\
\hline Interest & & $\begin{array}{c}-0.163 * * \\
(-2.38)\end{array}$ & & $\begin{array}{c}-0.136^{*} \\
(-1.96)\end{array}$ & & $\begin{array}{c}-0.147 * * \\
(-2.11)\end{array}$ & & $\begin{array}{c}-0.127 * \\
(-1.81)\end{array}$ \\
\hline LogAge & $\begin{array}{l}0.161 \\
(0.81)\end{array}$ & $\begin{array}{l}0.001 \\
(0.03)\end{array}$ & $\begin{array}{l}0.189 \\
(0.84)\end{array}$ & $\begin{array}{l}0.010 \\
(0.22)\end{array}$ & $\begin{array}{l}0.147 \\
(0.73)\end{array}$ & $\begin{array}{l}0.016 \\
(0.34)\end{array}$ & $\begin{array}{l}0.175 \\
(0.78)\end{array}$ & $\begin{array}{l}0.021 \\
(0.46)\end{array}$ \\
\hline Coupon & $\begin{array}{l}0.071 \\
(1.20)\end{array}$ & $\begin{array}{c}0.941 * * * \\
(36.54)\end{array}$ & $\begin{array}{l}0.084 \\
(1.51)\end{array}$ & $\begin{array}{c}0.942 * * * \\
(37.89)\end{array}$ & $\begin{array}{l}0.085 \\
(1.38)\end{array}$ & $\begin{array}{c}0.927 * * * \\
(33.40)\end{array}$ & $\begin{array}{l}0.101^{*} \\
(1.72)\end{array}$ & $\begin{array}{c}0.929 * * * \\
(34.61)\end{array}$ \\
\hline Aft2010 & $\begin{array}{l}-0.315 \\
(-1.63)\end{array}$ & $\begin{array}{c}-0.276^{* * *} \\
(-3.58)\end{array}$ & $\begin{array}{l}-0.292 \\
(-1.54)\end{array}$ & $\begin{array}{c}-0.269 * * * \\
(-3.67)\end{array}$ & $\begin{array}{c}-0.351^{*} \\
(-1.72)\end{array}$ & $\begin{array}{c}-0.231 * * * \\
(-2.88)\end{array}$ & $\begin{array}{c}-0.331^{*} \\
(-1.65)\end{array}$ & $\begin{array}{c}-0.229 * * * \\
(-2.98)\end{array}$ \\
\hline BenchUti & & & $\begin{array}{l}0.470 \\
(0.59)\end{array}$ & $\begin{array}{l}0.225 \\
(1.37)\end{array}$ & & & $\begin{array}{l}0.508 \\
(0.63)\end{array}$ & $\begin{array}{l}0.186 \\
(1.15)\end{array}$ \\
\hline BenchFee & & & & & $\begin{array}{l}0.102 \\
(0.70)\end{array}$ & $\begin{array}{c}-0.100^{*} \\
(-1.92)\end{array}$ & $\begin{array}{l}0.116 \\
(0.76)\end{array}$ & $\begin{array}{c}-0.098^{*} \\
(-1.93)\end{array}$ \\
\hline LogSize & $\begin{array}{l}0.763 * \\
(1.82)\end{array}$ & $\begin{array}{c}0.270 * * * \\
(2.63)\end{array}$ & $\begin{array}{l}0.644 \\
(1.57)\end{array}$ & $\begin{array}{c}0.233 * * \\
(2.22)\end{array}$ & $\begin{array}{l}0.744 * \\
(1.77)\end{array}$ & $\begin{array}{c}0.280 * * * \\
(2.77)\end{array}$ & $\begin{array}{l}0.613 \\
(1.47)\end{array}$ & $\begin{array}{c}0.245^{* *} \\
(2.35)\end{array}$ \\
\hline Longmat & $\begin{array}{c}9.529 * * * \\
(3.19)\end{array}$ & & $\begin{array}{c}9.207 * * * \\
(3.09)\end{array}$ & & $\begin{array}{c}9.203 * * * \\
(3.09)\end{array}$ & & $\begin{array}{c}8.812 * * * \\
(2.95)\end{array}$ & \\
\hline LogSize*Longmat & $\begin{array}{c}-1.172 * * * \\
(-3.36)\end{array}$ & & $\begin{array}{c}-1.135^{* * *} \\
(-3.28)\end{array}$ & & $\begin{array}{c}-1.134 * * * \\
(-3.26)\end{array}$ & & $\begin{array}{c}-1.089 * * * \\
(-3.14)\end{array}$ & \\
\hline Reopening & $\begin{array}{l}0.212^{*} \\
(1.80)\end{array}$ & & $\begin{array}{l}0.207^{*} \\
(1.79)\end{array}$ & & $\begin{array}{l}0.211^{*} \\
(1.79)\end{array}$ & & $\begin{array}{l}0.206^{*} \\
(1.79)\end{array}$ & \\
\hline Relimp & $\begin{array}{c}2.581 * * * \\
(3.32)\end{array}$ & & $\begin{array}{c}2.991 * * * \\
(2.57)\end{array}$ & & $\begin{array}{c}2.526 * * * \\
(3.23)\end{array}$ & & $\begin{array}{c}2.961 * * \\
(2.54)\end{array}$ & \\
\hline Constant & & $\begin{array}{c}-1.809 * * \\
(-1.97) \\
\end{array}$ & & $\begin{array}{c}-1.674^{*} \\
(-1.88) \\
\end{array}$ & & $\begin{array}{c}-1.721 * * \\
(-1.96) \\
\end{array}$ & & $\begin{array}{c}-1.566^{*} \\
(-1.82) \\
\end{array}$ \\
\hline Observations & 296 & 296 & 296 & 296 & 296 & 296 & 296 & 296 \\
\hline R-squared & 0.251 & 0.957 & 0.249 & 0.960 & 0.249 & 0.959 & 0.249 & 0.961 \\
\hline
\end{tabular}




\section{Table 6. Daily Panel Regressions of German Treasury Yields based on Secondary Market Trade Prices}

The dependent variable is the daily yield-to-maturity in percentage, Yield, calculated based on the daily closing mid prices, following market conventions. LogSupply is the natural logarithm of the total supply while LogDemand is the natural logarithm of the total demand in the securities lending market in millions of EUR, based on the total supply and demand reported in IHS Markit data in USD and converted to EUR using daily exchange rates from the Statistical Warehouse of the ECB. LogFees is the natural logarithm of the annualized value-weighted average fee in percentage. $\log T T M$ is the natural logarithm of time-to-maturity of specific Germany treasury measured in years with 2-decimal accuracy. OnTheRun dummy takes the value of one for a specific security for the trading days when the specific security is on-the-run for its tenor. Utilization is the percentage of the total supply of the issue utilized, currently out on loan. Longmat dummy takes the value of one for issues with more than 10 years of remaining maturity, and LogDemand*Longmat, Uti*Longmat and LogFees*Longmat are interaction terms with LogDemand, Utilization and LogFees, respectively. The sample contains Germany nominal treasury securities lending market information based on IHS Markit data from July 2006 to June 2015. Coefficient estimates, reported from panel regression with year and bond fixed effects and clustered standard errors at the bond level, are reported with t-stats (in parenthesis). ***,**, and $*$ denote the $1 \%, 5 \%$ and $10 \%$ significance levels.

Panel A. Panel Regression Results of Bond Yields with Securities Lending Variables

\begin{tabular}{|c|c|c|c|c|c|}
\hline & $\begin{array}{c}(1) \\
\text { Yield }\end{array}$ & $\begin{array}{c}(2) \\
\text { Yield } \\
\end{array}$ & $\begin{array}{c}(3) \\
\text { Yield } \\
\end{array}$ & $\begin{array}{c}(4) \\
\text { Yield }\end{array}$ & $\begin{array}{c}(5) \\
\text { Yield }\end{array}$ \\
\hline Utilization & & $\begin{array}{c}-0.306^{* * *} \\
(-4.93)\end{array}$ & $\begin{array}{c}-0.311 * * * \\
(-5.18)\end{array}$ & & \\
\hline LogSupply & & & $\begin{array}{l}0.003 \\
(0.63)\end{array}$ & $\begin{array}{c}0.022 * * \\
(2.01)\end{array}$ & $\begin{array}{c}0.024 * \\
(1.69)\end{array}$ \\
\hline LogDemand & & & & $\begin{array}{c}-0.031 * * \\
(-2.40)\end{array}$ & $\begin{array}{c}-0.037 * * \\
(-2.18)\end{array}$ \\
\hline LogFees & & & & & $\begin{array}{c}-0.077 * * * \\
(-5.69)\end{array}$ \\
\hline LogTTM & $\begin{array}{c}1.204 * * * \\
(12.10)\end{array}$ & $\begin{array}{c}1.143 * * * \\
(12.11)\end{array}$ & $\begin{array}{c}1.142 * * * \\
(12.16)\end{array}$ & $\begin{array}{c}1.185 * * * \\
(11.83)\end{array}$ & $\begin{array}{c}1.190 * * * \\
(11.64)\end{array}$ \\
\hline OnTheRun & $\begin{array}{c}0.126^{*} \\
(1.87)\end{array}$ & $\begin{array}{l}0.096 \\
(1.46)\end{array}$ & $\begin{array}{l}0.097 \\
(1.48)\end{array}$ & $\begin{array}{l}0.108 \\
(1.59)\end{array}$ & $\begin{array}{c}0.117 * \\
(1.72)\end{array}$ \\
\hline Constant & $\begin{array}{c}0.835^{* * * *} \\
(3.29) \\
\end{array}$ & $\begin{array}{c}1.147 * * * \\
(4.71) \\
\end{array}$ & $\begin{array}{c}1.130 * * * \\
(4.50)\end{array}$ & $\begin{array}{c}0.927 * * * \\
(3.48) \\
\end{array}$ & $\begin{array}{c}1.079 * * * \\
(3.92) \\
\end{array}$ \\
\hline Time and bond FE & Yes & Yes & Yes & Yes & Yes \\
\hline Observations & 115,574 & 115,574 & 115,574 & 115,574 & 112,851 \\
\hline R-squared & 0.929 & 0.930 & 0.930 & 0.929 & 0.929 \\
\hline
\end{tabular}




\section{Table 6. Continued}

Panel B. Panel Regression Results of Bond Yields with Securities Lending Variables in Conjunction with Long Maturities

\begin{tabular}{|c|c|c|c|c|c|}
\hline & $\begin{array}{c}(1) \\
\text { Yield }\end{array}$ & $\begin{array}{c}(2) \\
\text { Yield }\end{array}$ & $\begin{array}{c}(3) \\
\text { Yield }\end{array}$ & $\begin{array}{c}(4) \\
\text { Yield }\end{array}$ & $\begin{array}{c}(5) \\
\text { Yield }\end{array}$ \\
\hline Utilization & & & $\begin{array}{c}-0.209 * * * \\
(-2.78)\end{array}$ & $\begin{array}{c}-0.318 * * * \\
(-5.38)\end{array}$ & $\begin{array}{c}-0.209 * * * \\
(-2.87)\end{array}$ \\
\hline LogSupply & $\begin{array}{c}0.024 * \\
(1.70)\end{array}$ & $\begin{array}{c}0.024 * \\
(1.67)\end{array}$ & $\begin{array}{l}-0.000 \\
(-0.02)\end{array}$ & $\begin{array}{l}-0.000 \\
(-0.00)\end{array}$ & $\begin{array}{l}-0.000 \\
(-0.02)\end{array}$ \\
\hline LogDemand & $\begin{array}{c}-0.037 * * \\
(-2.18)\end{array}$ & $\begin{array}{c}-0.037 * * \\
(-2.22)\end{array}$ & & & \\
\hline LogFees & $\begin{array}{c}-0.078 * * * \\
(-5.78)\end{array}$ & $\begin{array}{c}-0.078 * * * \\
(-5.74)\end{array}$ & $\begin{array}{c}-0.089 * * * \\
(-6.71)\end{array}$ & $\begin{array}{c}-0.128 * * * \\
(-7.94)\end{array}$ & $\begin{array}{c}-0.124 * * * \\
(-7.83)\end{array}$ \\
\hline Longmat & $\begin{array}{c}0.310^{* * * *} \\
(3.38)\end{array}$ & $\begin{array}{c}0.313^{* *} \\
(2.57)\end{array}$ & $\begin{array}{c}0.517 * * * \\
(5.49)\end{array}$ & $\begin{array}{l}-0.199 \\
(-1.51)\end{array}$ & $\begin{array}{l}0.029 \\
(0.26)\end{array}$ \\
\hline LogDemand*Longmat & & $\begin{array}{l}-0.000 \\
(-0.03)\end{array}$ & & & \\
\hline Uti*Longmat & & & $\begin{array}{c}-0.594 * * * \\
(-3.71)\end{array}$ & & $\begin{array}{c}-0.491 * * * \\
(-3.13)\end{array}$ \\
\hline LogFees*Longmat & & & & $\begin{array}{c}0.197 * * * \\
(5.75)\end{array}$ & $\begin{array}{c}0.174 * * * \\
(5.44)\end{array}$ \\
\hline LogTTM & $\begin{array}{c}1.199 * * * \\
(11.85)\end{array}$ & $\begin{array}{c}1.199 * * * \\
(11.72)\end{array}$ & $\begin{array}{c}1.079 * * * \\
(10.96)\end{array}$ & $\begin{array}{c}1.064 * * * \\
(11.16)\end{array}$ & $\begin{array}{c}1.014 * * * \\
(10.37)\end{array}$ \\
\hline OnTheRun & $\begin{array}{l}0.098 \\
(1.44)\end{array}$ & $\begin{array}{l}0.098 \\
(1.44)\end{array}$ & $\begin{array}{l}0.090 \\
(1.45)\end{array}$ & $\begin{array}{l}0.075 \\
(1.17)\end{array}$ & $\begin{array}{l}0.080 \\
(1.30)\end{array}$ \\
\hline Constant & $\begin{array}{c}0.984 * * * \\
(3.55)\end{array}$ & $\begin{array}{c}0.984 * * * \\
(3.57)\end{array}$ & $\begin{array}{c}1.382 * * * \\
(4.89)\end{array}$ & $\begin{array}{c}1.565^{* * * *} \\
(5.99) \\
\end{array}$ & $\begin{array}{c}1.653 * * * \\
(6.03)\end{array}$ \\
\hline Time and Bond FE & Yes & Yes & Yes & Yes & Yes \\
\hline Observations & 112,851 & 112,851 & 112,851 & 112,851 & 112,851 \\
\hline R-squared & 0.930 & 0.930 & 0.932 & 0.932 & 0.932 \\
\hline
\end{tabular}




\section{Table 7. Lending Fee Dynamics With Realized Demand/Supply Shocks in the Securities Lending Market}

The dependent variable LogFees is the natural logarithm of the annualized value-weighted average fee in percentage. LogDemand and LogSupply are lagged by 3 days. DemIncrease -1 and its two- and three-day lagged values are defined as the $2 \%$ increase in demand in the securities lending market from one day to the next. Longmat*DemIncrease is the interaction term between the different lagged values o DemIncrease and Longmat, where the Longmat dummy takes the value of one for issues with more than 10 years of remaining maturity. LogTTM and OnTheRun are defined in Tables 1 and 2 or are lagged values of those variables defined in the tables, where the lags are indicated in the subscripts. The sample contains Germany nominal treasury securities lending market information based on IHS Markit data from July 2006 to June 2015. Coefficient estimates, reported from panel regression with year and bond fixed effects and clustered standard errors at the bond level, are reported with t-stats (in parenthesis). $* * *, * *$, and $*$ denote the $1 \%, 5 \%$ and $10 \%$ significance levels.

\begin{tabular}{|c|c|c|c|c|c|c|}
\hline & $\begin{array}{c}(1) \\
\text { LogFees } \\
\end{array}$ & $\begin{array}{c}(2) \\
\text { LogFees } \\
\end{array}$ & $\begin{array}{c}(3) \\
\text { LogFees } \\
\end{array}$ & $\begin{array}{c}(4) \\
\text { LogFees } \\
\end{array}$ & $\begin{array}{c}(5) \\
\text { LogFees } \\
\end{array}$ & $\begin{array}{c}(6) \\
\text { LogFees } \\
\end{array}$ \\
\hline $\operatorname{LogDemand}_{-3}$ & $\begin{array}{l}0.019 \\
(1.63)\end{array}$ & $\begin{array}{c}0.019^{*} \\
(1.69)\end{array}$ & $\begin{array}{l}0.018 \\
(1.52)\end{array}$ & $\begin{array}{c}0.019^{*} \\
(1.68)\end{array}$ & $\begin{array}{c}0.020^{*} \\
(1.75)\end{array}$ & $\begin{array}{l}0.019 \\
(1.60)\end{array}$ \\
\hline $\operatorname{LogSupply}_{-3}$ & $\begin{array}{c}-0.028 * * * \\
(-2.89)\end{array}$ & $\begin{array}{c}-0.028 * * * \\
(-2.91)\end{array}$ & $\begin{array}{c}-0.029 * * * \\
(-3.11)\end{array}$ & $\begin{array}{c}-0.028 * * * \\
(-2.94)\end{array}$ & $\begin{array}{c}-0.028 * * * \\
(-2.96)\end{array}$ & $\begin{array}{c}-0.030 * * * \\
(-3.21)\end{array}$ \\
\hline DemIncrease $_{-1}$ & $\begin{array}{c}0.036 * * \\
(2.20)\end{array}$ & $\begin{array}{c}0.038 * * \\
(2.23)\end{array}$ & $\begin{array}{c}0.038 * * \\
(2.22)\end{array}$ & $\begin{array}{c}0.036 * * \\
(2.50)\end{array}$ & $\begin{array}{c}0.039 * * \\
(2.58)\end{array}$ & $\begin{array}{c}0.038 * * \\
(2.54)\end{array}$ \\
\hline DemIncrease $_{-2}$ & & $\begin{array}{c}0.024^{*} \\
(1.78)\end{array}$ & $\begin{array}{l}0.020 \\
(1.34)\end{array}$ & & $\begin{array}{c}0.028 * * \\
(2.02)\end{array}$ & $\begin{array}{l}0.025 \\
(1.59)\end{array}$ \\
\hline DemIncrease $_{-3}$ & & & $\begin{array}{l}-0.026 \\
(-1.53)\end{array}$ & & & $\begin{array}{l}-0.018 \\
(-0.95)\end{array}$ \\
\hline Longmat & & & & $\begin{array}{l}0.158 \\
(1.47)\end{array}$ & $\begin{array}{l}0.159 \\
(1.47)\end{array}$ & $\begin{array}{l}0.167 \\
(1.53)\end{array}$ \\
\hline DemIncrease $_{-1} *$ Longmat & & & & $\begin{array}{l}-0.004 \\
(-0.07)\end{array}$ & $\begin{array}{l}-0.005 \\
(-0.10)\end{array}$ & $\begin{array}{l}-0.002 \\
(-0.04)\end{array}$ \\
\hline DemIncrease $_{-2} *$ Longmat & & & & & $\begin{array}{l}-0.019 \\
(-0.49)\end{array}$ & $\begin{array}{l}-0.022 \\
(-0.54)\end{array}$ \\
\hline DemIncrease $_{-3} *$ Longmat & & & & & & $\begin{array}{l}-0.038 \\
(-1.15)\end{array}$ \\
\hline $\operatorname{LogTTM}$ & $\begin{array}{l}0.043 \\
(0.46)\end{array}$ & $\begin{array}{l}0.041 \\
(0.44)\end{array}$ & $\begin{array}{l}0.043 \\
(0.46)\end{array}$ & $\begin{array}{l}0.047 \\
(0.50)\end{array}$ & $\begin{array}{l}0.045 \\
(0.48)\end{array}$ & $\begin{array}{l}0.044 \\
(0.47)\end{array}$ \\
\hline OnTheRun & $\begin{array}{c}0.089 * \\
(1.66)\end{array}$ & $\begin{array}{l}0.089 \\
(1.65)\end{array}$ & $\begin{array}{l}0.088 \\
(1.63)\end{array}$ & $\begin{array}{l}0.080 \\
(1.55)\end{array}$ & $\begin{array}{l}0.080 \\
(1.54)\end{array}$ & $\begin{array}{l}0.077 \\
(1.49)\end{array}$ \\
\hline Constant & $\begin{array}{c}1.715^{* * *} \\
(7.23) \\
\end{array}$ & $\begin{array}{c}1.710^{* * *} \\
(7.22)\end{array}$ & $\begin{array}{c}1.735 * * * \\
(7.33) \\
\end{array}$ & $\begin{array}{c}1.666^{* * *} \\
(6.78) \\
\end{array}$ & $\begin{array}{c}1.664 * * * \\
(6.78) \\
\end{array}$ & $\begin{array}{c}1.693 * * * \\
(6.93)\end{array}$ \\
\hline Time and Bond FE & Yes & Yes & Yes & Yes & Yes & Yes \\
\hline Observations & 112,667 & 112,667 & 112,667 & 112,667 & 112,667 & 112,667 \\
\hline R-squared & 0.344 & 0.344 & 0.344 & 0.344 & 0.344 & 0.344 \\
\hline
\end{tabular}




\section{Table 8. Lending Fee Dynamics with Expected Supply and Demand Changes}

The dependent variable LogFees is the daily natural logarithm of the value-weighted average fees, as defined in Tables 1 and 2. LogSupply is the natural logarithm of the total supply while LogDemand is the natural logarithm of the total demand in the securities lending market in millions of EUR, based on the total supply and demand reported in IHS Markit data in USD and converted to EUR using daily exchange rates from the Statistical Warehouse of the European Central Bank. Longmat takes the value of one for issues with more than 10 years of remaining maturity. Repwind is a dummy variable that takes on the value of 1 for the last 5 days of the calendar year. Aft2010 is a dummy that takes on the value of one for year 2011 and thereafter. Repwind*Longmat, Repwind*Aft2010 and Aft2010*Repwind*Longmat are interaction variables of Repwind, Longmat and Aft2010, respectively. LogTTM and OnTheRun are defined in Tables 1 and 2 or are lagged values of those variables defined in the tables, where the lags are indicated in the subscripts. The sample contains Germany nominal treasury securities lending market information based on IHS Markit data from July 2006 to June 2015. Coefficient estimates, reported from panel regressions with bond and year fixed effects and clustered standard errors at the bond level, are reported with t-stats (in parenthesis). ${ }^{* * *},{ }^{* *}$, and $*$ denote the $1 \%, 5 \%$ and $10 \%$ significance levels.

\begin{tabular}{|c|c|c|c|c|}
\hline & $\begin{array}{c}(1) \\
\text { LogFees }\end{array}$ & $\begin{array}{c}(2) \\
\text { LogFees } \\
\end{array}$ & $\begin{array}{c}(3) \\
\text { LogFees } \\
\end{array}$ & $\begin{array}{c}(4) \\
\text { LogFees }\end{array}$ \\
\hline LogSupply & $\begin{array}{c}-0.028^{* * *} \\
(-4.05)\end{array}$ & $\begin{array}{c}-0.028 * * * \\
(-4.03)\end{array}$ & $\begin{array}{c}-0.028^{* * *} \\
(-4.03)\end{array}$ & $\begin{array}{c}-0.028 * * * \\
(-4.03)\end{array}$ \\
\hline Repwind & $\begin{array}{c}0.098 * * * \\
(4.63)\end{array}$ & $\begin{array}{c}0.080 * * * \\
(3.26)\end{array}$ & $\begin{array}{l}0.024 \\
(0.61)\end{array}$ & $\begin{array}{l}0.052 \\
(1.08)\end{array}$ \\
\hline LogSupply $_{-5}$ & $\begin{array}{c}-0.022 * * \\
(-2.51)\end{array}$ & $\begin{array}{c}-0.023^{* *} \\
(-2.57)\end{array}$ & $\begin{array}{c}-0.023^{* *} \\
(-2.57)\end{array}$ & $\begin{array}{c}-0.023 * * \\
(-2.58)\end{array}$ \\
\hline LogDemand $_{-5}$ & $\begin{array}{l}0.021^{*} \\
(1.95)\end{array}$ & $\begin{array}{c}0.022^{* *} \\
(2.03)\end{array}$ & $\begin{array}{c}0.022 * * \\
(2.03)\end{array}$ & $\begin{array}{c}0.022 * * \\
(2.04)\end{array}$ \\
\hline Longmat & & $\begin{array}{l}0.165 \\
(1.63)\end{array}$ & $\begin{array}{l}0.165 \\
(1.63)\end{array}$ & $\begin{array}{l}0.165 \\
(1.63)\end{array}$ \\
\hline Repwind*Longmat & & $\begin{array}{l}0.080^{*} \\
(1.69)\end{array}$ & $\begin{array}{l}0.079 * \\
(1.67)\end{array}$ & $\begin{array}{l}-0.050 \\
(-0.45)\end{array}$ \\
\hline Aft2010 & & & $\begin{array}{c}0.820^{* * *} \\
(5.55)\end{array}$ & $\begin{array}{c}0.818^{* * *} \\
(5.57)\end{array}$ \\
\hline Aft2010*Repwind & & & $\begin{array}{l}0.090^{*} \\
(1.83)\end{array}$ & $\begin{array}{l}0.045 \\
(0.78)\end{array}$ \\
\hline Aft2010*Repwind*Longmat & & & & $\begin{array}{l}0.204 \\
(1.39)\end{array}$ \\
\hline $\operatorname{LogTTM}$ & $\begin{array}{l}0.051 \\
(0.54)\end{array}$ & $\begin{array}{l}0.055 \\
(0.59)\end{array}$ & $\begin{array}{l}0.055 \\
(0.59)\end{array}$ & $\begin{array}{l}0.054 \\
(0.58)\end{array}$ \\
\hline OnTheRun & $\begin{array}{l}0.084 \\
(1.54)\end{array}$ & $\begin{array}{l}0.075 \\
(1.42)\end{array}$ & $\begin{array}{l}0.075 \\
(1.42)\end{array}$ & $\begin{array}{l}0.075 \\
(1.42)\end{array}$ \\
\hline Constant & $\begin{array}{c}1.852 * * * \\
(7.81) \\
\end{array}$ & $\begin{array}{c}1.799^{* * *} \\
(7.30) \\
\end{array}$ & $\begin{array}{c}1.800^{* * *} \\
(7.31)\end{array}$ & $\begin{array}{c}1.804 * * * \\
(7.35) \\
\end{array}$ \\
\hline Bond and Time FE & Yes & Yes & Yes & Yes \\
\hline Observations & 112,479 & 112,479 & 112,479 & 112,479 \\
\hline R-squared & 0.347 & 0.347 & 0.347 & 0.347 \\
\hline
\end{tabular}




\section{Table 9. Panel Regression Analysis of the Feespreads in Securities Lending}

The dependent variable is the Feespread, the difference between the highest and lowest securities lending fees on a given calendar day. Repwind is a dummy variable that takes on the value of 1 for the last 5 days of the calendar year, while Longmat is a dummy that takes the value of 1 for bonds with 10 years or longer maturity bonds. LogFees * Longmat is the interaction between the Longmat dummy and the natural logarithm of the valueweighted average lending fees (AllFees). Utilization is the percentage of the total supply of the issue utilized, currently out on loan. Uti*Longmat is the interaction terms of Utilization and Longmat. The LogDem *Longmat is the interaction between the Longmat dummy and the LogDemand. LogTTM and OnTheRun are defined in Tables 1 and 2. The sample contains Germany nominal treasury securities lending market information based on IHS Markit data from July 2006 to June 2015. Coefficient estimates, reported from panel regressions with bond and year fixed effects and clustered standard errors at the bond level, are reported with t-stats (in parenthesis). $* * *, * *$, and $*$ denote the $1 \%, 5 \%$ and $10 \%$ significance levels.

\begin{tabular}{|c|c|c|c|c|c|c|c|}
\hline & $\begin{array}{c}\text { (1) } \\
\text { Feespread }\end{array}$ & $\begin{array}{c}(2) \\
\text { Feespread }\end{array}$ & $\begin{array}{c}(3) \\
\text { Feespread }\end{array}$ & $\begin{array}{c}(4) \\
\text { Feespread }\end{array}$ & $\begin{array}{c}(5) \\
\text { Feespread }\end{array}$ & $\begin{array}{c}(6) \\
\text { Feespread }\end{array}$ & $\begin{array}{c}(7) \\
\text { Feespread }\end{array}$ \\
\hline LogSupply & $\begin{array}{c}0.716^{* * *} \\
(12.32)\end{array}$ & $\begin{array}{c}0.716^{* * *} \\
(12.32)\end{array}$ & $\begin{array}{c}0.716^{* * * *} \\
(12.47)\end{array}$ & $\begin{array}{c}0.717 * * * \\
(12.35)\end{array}$ & $\begin{array}{c}0.717 * * * \\
(12.50)\end{array}$ & $\begin{array}{c}0.619 * * * \\
(7.76)\end{array}$ & $\begin{array}{c}0.621 * * * \\
(7.82)\end{array}$ \\
\hline Repwind & $\begin{array}{c}0.136 * * * \\
(4.75)\end{array}$ & $\begin{array}{c}0.135 * * * \\
(4.77)\end{array}$ & $\begin{array}{c}0.135 * * * \\
(4.79)\end{array}$ & $\begin{array}{c}0.131 * * * \\
(4.67)\end{array}$ & $\begin{array}{c}0.131 * * * \\
(4.70)\end{array}$ & $\begin{array}{c}0.149 * * * \\
(5.20)\end{array}$ & $\begin{array}{c}0.153 * * * \\
(5.50)\end{array}$ \\
\hline LogFees & $\begin{array}{c}0.141 * * * \\
(5.86)\end{array}$ & $\begin{array}{c}0.141 * * * \\
(5.84)\end{array}$ & $\begin{array}{c}0.141 * * * \\
(5.85)\end{array}$ & $\begin{array}{c}0.124 * * * \\
(4.14)\end{array}$ & $\begin{array}{c}0.124 * * * \\
(4.16)\end{array}$ & $\begin{array}{c}0.146^{* * * *} \\
(6.16)\end{array}$ & $\begin{array}{c}0.146^{* * *} \\
(6.14)\end{array}$ \\
\hline Utilization & $\begin{array}{c}-0.607 * * * \\
(-3.52)\end{array}$ & $\begin{array}{c}-0.607 * * * \\
(-3.52)\end{array}$ & $\begin{array}{c}-0.598 * * * \\
(-3.20)\end{array}$ & $\begin{array}{c}-0.595 * * * \\
(-3.47)\end{array}$ & $\begin{array}{c}-0.593 * * * \\
(-3.19)\end{array}$ & & \\
\hline Longmat & & $\begin{array}{l}0.071 \\
(0.68)\end{array}$ & $\begin{array}{l}0.086 \\
(0.49)\end{array}$ & $\begin{array}{l}-0.154 \\
(-0.71)\end{array}$ & $\begin{array}{l}-0.151 \\
(-0.59)\end{array}$ & $\begin{array}{l}0.070 \\
(0.63)\end{array}$ & $\begin{array}{l}-0.354 \\
(-0.51)\end{array}$ \\
\hline Uti*Longmat & & & $\begin{array}{l}-0.042 \\
(-0.11)\end{array}$ & & $\begin{array}{l}-0.008 \\
(-0.02)\end{array}$ & & \\
\hline LogFees*Longmat & & & & $\begin{array}{l}0.085 \\
(1.19)\end{array}$ & $\begin{array}{l}0.085 \\
(1.20)\end{array}$ & & \\
\hline LogDemand & & & & & & $\begin{array}{c}0.091 * \\
(1.77)\end{array}$ & $\begin{array}{l}0.075 \\
(1.39)\end{array}$ \\
\hline LogDem*Longmat & & & & & & & $\begin{array}{l}0.066 \\
(0.64)\end{array}$ \\
\hline LogTTM & $\begin{array}{c}-0.518 * * * \\
(-4.81)\end{array}$ & $\begin{array}{c}-0.516^{* * *} \\
(-4.78)\end{array}$ & $\begin{array}{c}-0.522 * * * \\
(-4.36)\end{array}$ & $\begin{array}{c}-0.554 * * * \\
(-4.77)\end{array}$ & $\begin{array}{c}-0.555^{* * *} \\
(-4.40)\end{array}$ & $\begin{array}{c}-0.353 * * * \\
(-3.27)\end{array}$ & $\begin{array}{c}-0.319 * * \\
(-2.52)\end{array}$ \\
\hline OnTheRun & $\begin{array}{l}0.003 \\
(0.04)\end{array}$ & $\begin{array}{l}-0.001 \\
(-0.02)\end{array}$ & $\begin{array}{l}-0.001 \\
(-0.01)\end{array}$ & $\begin{array}{l}-0.005 \\
(-0.06)\end{array}$ & $\begin{array}{l}-0.005 \\
(-0.06)\end{array}$ & $\begin{array}{l}0.059 \\
(0.70)\end{array}$ & $\begin{array}{l}0.058 \\
(0.69)\end{array}$ \\
\hline Constant & $\begin{array}{l}-0.544 \\
(-1.14) \\
\end{array}$ & $\begin{array}{r}-0.566 \\
(-1.17) \\
\end{array}$ & $\begin{array}{l}-0.554 \\
(-1.04) \\
\end{array}$ & $\begin{array}{l}-0.427 \\
(-0.83) \\
\end{array}$ & $\begin{array}{l}-0.425 \\
(-0.77) \\
\end{array}$ & $\begin{array}{c}-1.229 * * \\
(-2.28) \\
\end{array}$ & $\begin{array}{c}-1.232 * * \\
(-2.37) \\
\end{array}$ \\
\hline Bond and Time FE & Yes & Yes & Yes & Yes & Yes & Yes & Yes \\
\hline Observations & 104,505 & 104,505 & 104,505 & 104,505 & 104,505 & 104,505 & 104,505 \\
\hline R-squared & 0.461 & 0.461 & 0.461 & 0.461 & 0.461 & 0.454 & 0.454 \\
\hline
\end{tabular}


Clearstream Triparty Repo Services is designed to simplify the process of administering multicurrency repurchase agreements for both Collateral Receivers and Collateral Givers, reduces operational risks through an effective delivery against payment settlement process and it is a comprehensive securities safekeeping service. Collateral received in connection with a triparty repo exposure is monitored and marked-to-market on a daily basis to ensure that collateral margin requirements are maintained.

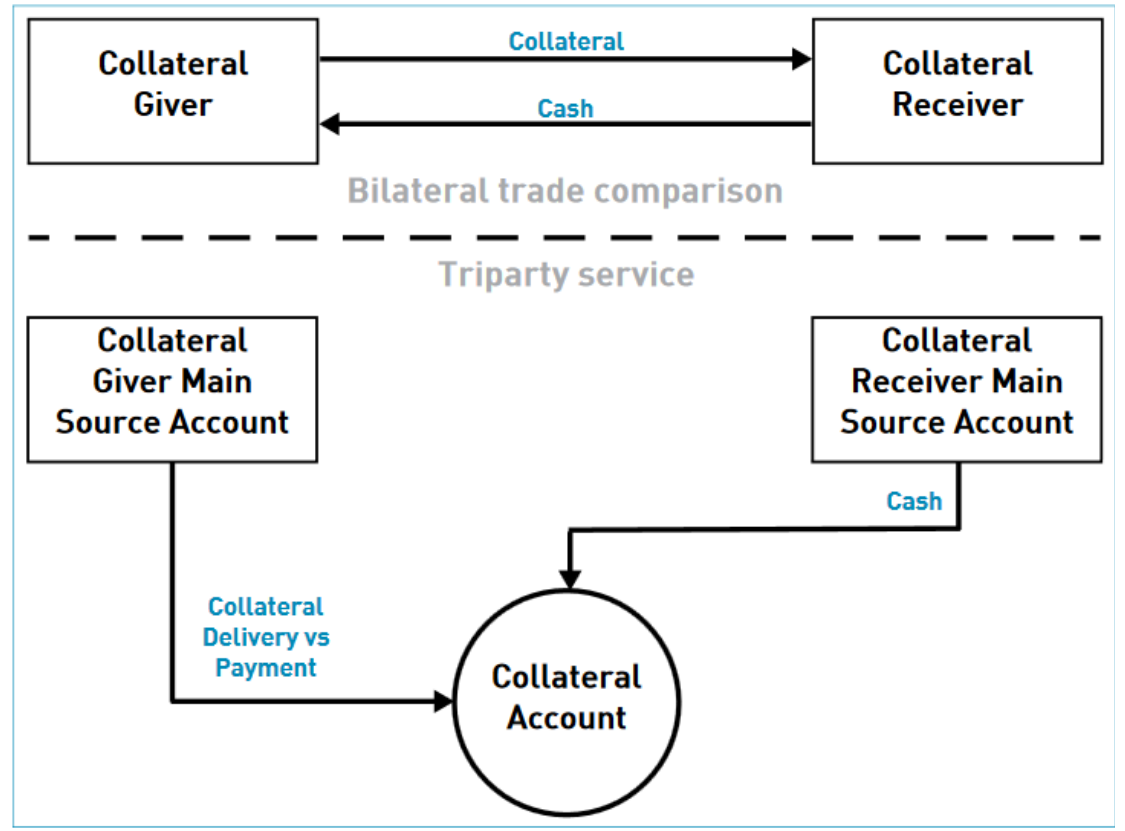

Clearstream Triparty Securities Lending Service provides complete settlement and valuation of a securities loan, as well as the related collateral management for the duration of the trade. Simultaneous exchange of the loan principal against collateral enables settlement of both sides of the transaction, thus reducing risk and increasing efficiency. The collateral is allocated to a special segregated account (the collateral account) and is marked-tomarket daily. Detailed and comprehensive reporting is sent to both counterparties.

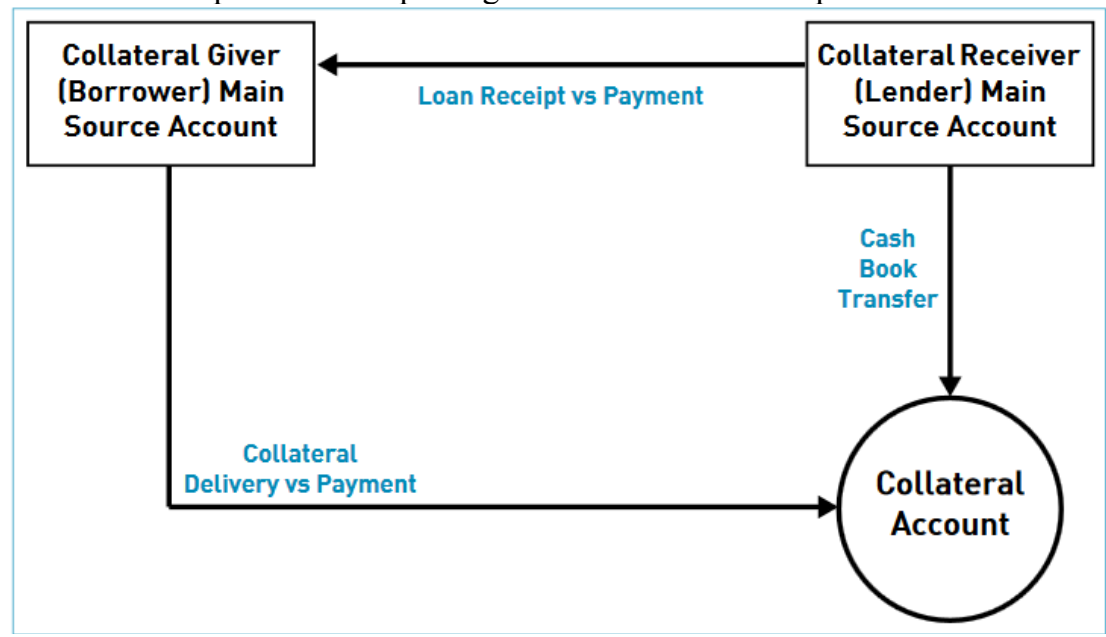

Figure 1. Securities Financing Transactions: Securities Lending vs. Repo

Source: Triparty Collateral Management Service (CmaX), Clearstream

http://www.clearstream.com/blob/9766/33fa44d6dcc545ff41880d5d0115861d/cmax-product-guide-pdf-data.pdf 

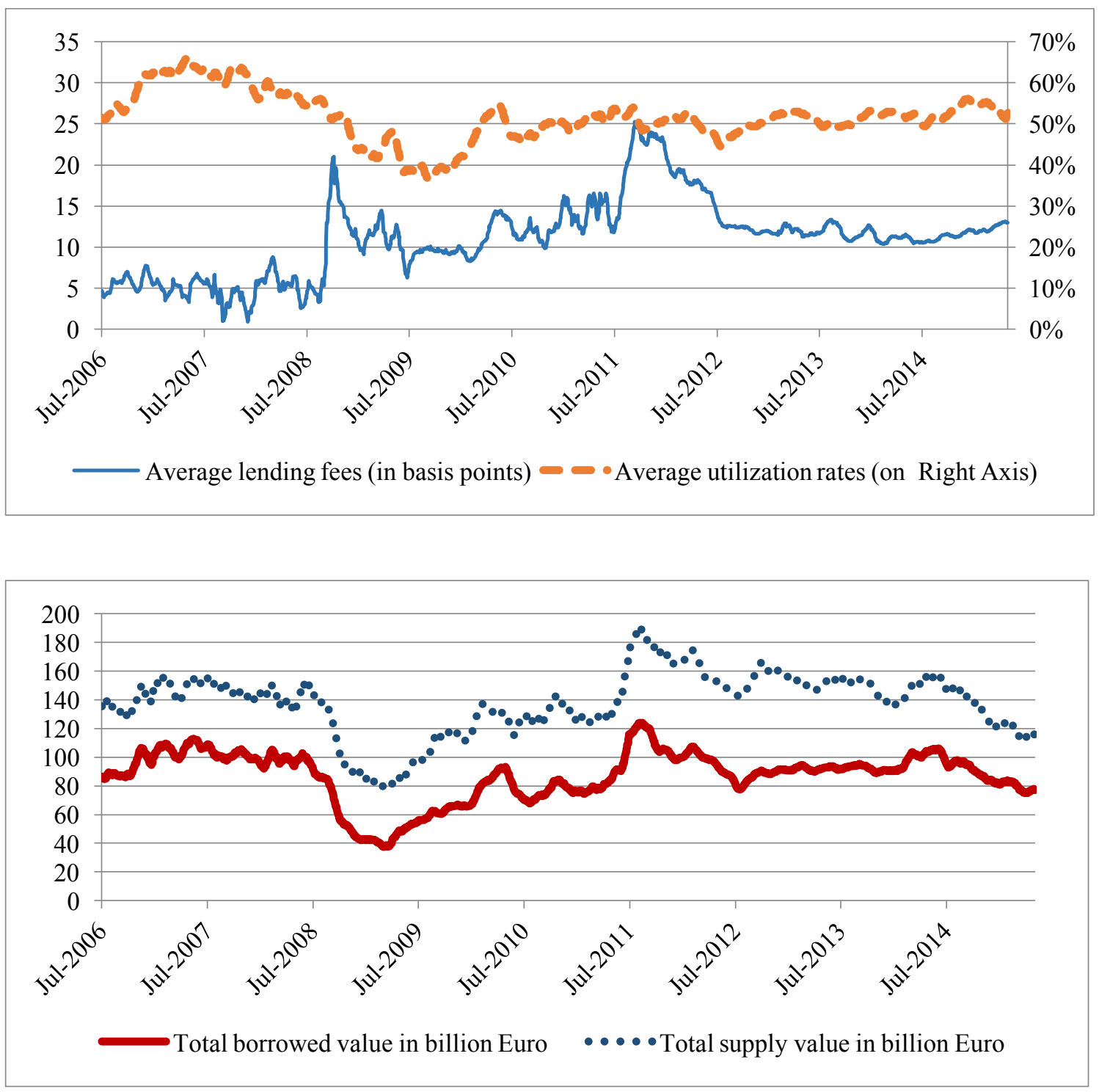

Figure 2. Time-series of Average Securities Lending Market Variables for German Sovereign Bonds The figures depict the time-series of average lending market variables for German sovereign bonds from July 2006 to June 2015. The top panel shows the time-series of the monthly moving average lending fee and utilization rates across all available German nominal sovereign bonds in our sample, while the bottom panel depicts the aggregate shorted value and supply value in the market in billions of euros. 



Figure 3. Cumulative Returns on Major Stock Indices and Long-Term German Nominal Sovereign Bonds

The figure shows the cumulative returns on S\&P500 Index (SP500), Deutscher Aktien Index (DAX), and the cumulative yield on portfolio of long German sovereign bonds. 
Stage 1 (Purchase):

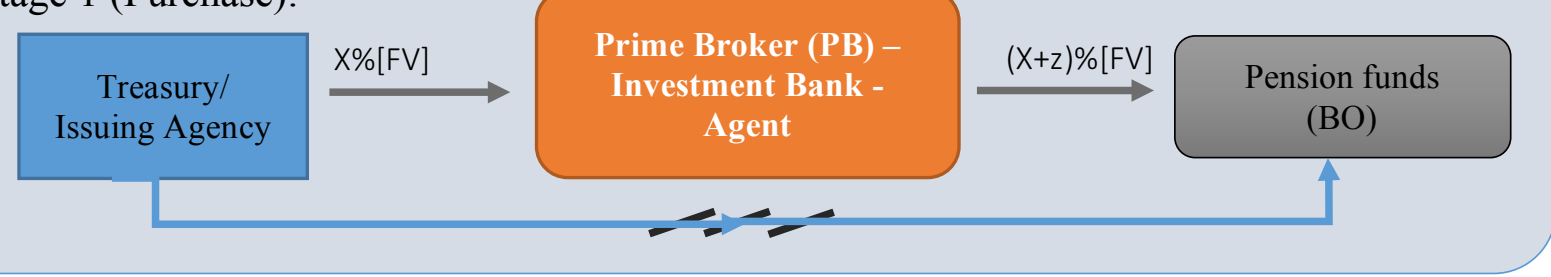

Stage 2 (Multi Year Phase)

(repeated game: Lending $)^{*}$

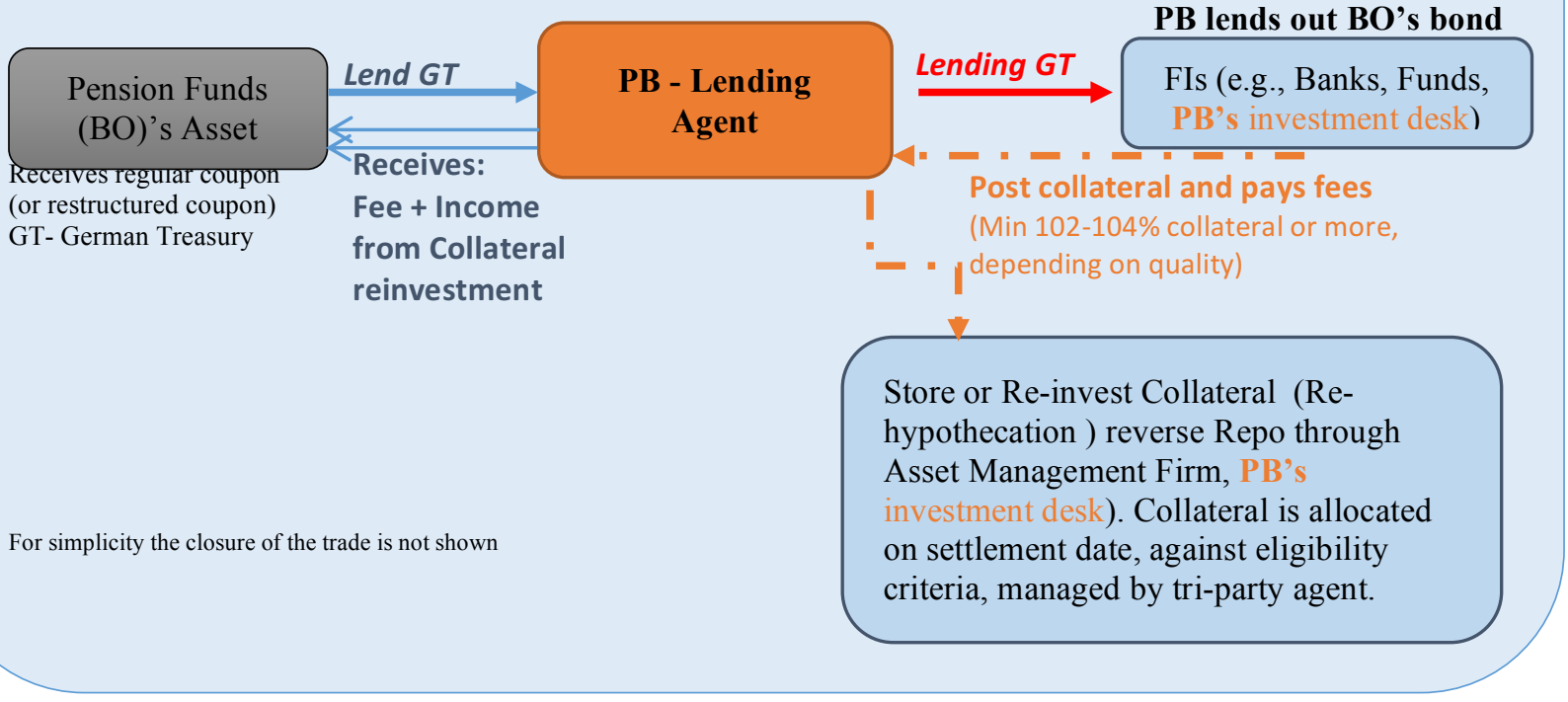

*In Step 2, at times when there is no demand for the asset in the securities lending market, the prime brokeragent, can act as or arrange custodian services.

Stage 3 (Redemption): The Treasury or issuing agency directly redeems the bond, the pension fund receives the principal and last coupon payment.

Figure 4. Treasury Investment Life-Cycle for Pension Funds and Insurance Firms with Buy-and-Hold Strategy

The figure provides tentative explanation for the life-cycle of treasury holdings by pension funds or insurance firms, as these investors are engage in a buy and hold strategy. ${ }^{17}$

${ }^{17}$ The German Finanzagentur indicates that pension funds and retail investors are responsible to less than $1 \%$ of the total trading volume, indicating that they are generally buy and hold investors (source: https://www.deutsche-finanzagentur.de/en/institutional-investors/secondary-market/structures/) 


\title{
Online Appendix for The Pricing Implications of Oligopolistic Securities Lending Market: A Beneficial Owner Perspective
}

\author{
Online Appendix A. Overview of the German Treasury Market
}

\section{Primary Market of German Sovereign Bonds}

The Finanzagentur has been responsible for issuing German Federal securities on behalf of the German government since June 2001. German sovereign debt issues are not only highly liquid; they also carry low risk, reflected by the continuous AAA rating throughout the Euro crisis. German government bonds are available in various maturities, such as 6- and 12-month maturity treasury discount papers, 2-year maturity Federal treasury notes (Schaetze); five-year maturity Federal notes (Bobls) and 10- and 30-year maturity Federal bonds (Bunds). The two-year notes account for $9 \%$ of the outstanding tradable German public debt and about $11 \%$ of the total trading volume, while five-year notes account for about $20 \%$ of the outstanding public debt and constitute about $17 \%$ of the overall trading volume. Overall, the 2-year, 5-year, 10-year, and 30-year treasuries account for about $90 \%$ of the total outstanding tradable government debt (stock) and $70 \%$ of the total issuance (flow),(Finanzagentur, 2015).

The Finanzagentur reports that $90 \%$ of the funding needs of the Federal Government are covered by placing issues to primary dealers in the form of single issues via auctions, where the dealers are approved financial institutions, members of the Bund Issues Auction Group. In principle, any EU credit or securities trading institution or investment firm can become a member of the Auction Group, with no obligation to bid at the auctions. The publicly disseminated issuance calendar is released in a year in advance, and provides information on all forthcoming issuances including the type of the security, the day of the issuance, maturity date, and targeted nominal issuance amount. Such high level of transparency and detailed schedule makes the German government a globally recognized and reliable issuer. All regularly issued capital market securities are issued in a tender process, where members of the Bund Issues Auction Group participate in a multi-price auction. As such, the bids are allotted at the price specified in the bid, not at a single price. Bids that are above the lowest accepted bid are allotted in full. At the end of the auction, the allotted amounts are published in the Bund Bidding System, and the information is subsequently released to the public. For each auction, the government retains a certain amount of the nominal volume issued, which is gradually introduced into the secondary market following the tender. Moreover, for some issues, auctions are also followed by multiple reopenings to facilitate liquidity management in the market and the delivery of futures written on these bonds.

\section{Secondary Market of German Sovereign Bond}

All German capital market securities are traded on stock exchanges, international electronic trading platforms, and OTC. They are quoted by market makers throughout the trading day and at the tightest bid-ask spreads of all euro-denominated sovereign debt securities. Quotes are at a voluntary basis; thus, no artificial liquidity or market depth are created. According to the statistics of the Finanzagentur, the average yearly trading volume of capital market securities was EUR 5.7 trillion between 2006 and 2015. In 2015 an average nominal volume of EUR 1.1 trillion was in circulation, and this amount has turned over 4-6 times every year for the same period. The corresponding daily trading volumes were in the magnitude of EUR 19 billion. According to the information supplied by a representative sample of primary dealers, most trading activity of German debt securities takes place between European and Euro area counterparties. Looking at the institutional shares of trades, the Finance Agency reports that the most important parties are brokers, asset managers, and banks, with a slight increase in hedge fund and decrease in central bank transactions. The liquidity of German bonds is also supported by futures contracts traded on the Eurex. While future contracts are available on most bonds with 2-, 5-, 10- and 30-year maturities, the most liquid products are those linked to 10-year Federal Bunds with a turnover of 177 million contracts traded yearly, in the volume of EUR 27 trillion in 2015. Last, the securities that are retained at the auctions are mostly sold in the secondary market, to collateralize repos or interest rate swaps or to be used in securities lending. Next to providing additional liquidity and facilitating delivery of specific securities, the Finanzagentur and the Deutsche Bundesbank also act as market-makers on the different platforms, where German public debt is traded. Nevertheless, both institutions aim to minimize the price impact of their secondary market transactions. 
Appendix B. Complete Tables, Displaying Additional Fixed Effects

A. Table 6. Daily Panel Regressions of German Treasury Yields based on Secondary Market Trade Prices, full specification with Displaying Year Fixed Effects

\begin{tabular}{|c|c|c|c|c|c|}
\hline & $\begin{array}{c}(1) \\
\text { Yield } \\
\end{array}$ & $\begin{array}{c}(2) \\
\text { Yield } \\
\end{array}$ & $\begin{array}{c}(3) \\
\text { Yield } \\
\end{array}$ & $\begin{array}{c}(4) \\
\text { Yield } \\
\end{array}$ & $\begin{array}{c}(5) \\
\text { Yield } \\
\end{array}$ \\
\hline Utilization & & $\begin{array}{c}-0.306^{* * *} \\
(-4.93)\end{array}$ & $\begin{array}{c}-0.311 * * * \\
(-5.18)\end{array}$ & & \\
\hline LogSupply & & & $\begin{array}{l}0.003 \\
(0.63)\end{array}$ & $\begin{array}{c}0.022 * * \\
(2.01)\end{array}$ & $\begin{array}{c}0.024 * \\
(1.69)\end{array}$ \\
\hline LogDemand & & & & $\begin{array}{c}-0.031 * * \\
(-2.40)\end{array}$ & $\begin{array}{c}-0.037 * * \\
(-2.18)\end{array}$ \\
\hline LogFees & & & & & $\begin{array}{c}-0.077 * * * \\
(-5.69)\end{array}$ \\
\hline LogTTM & $\begin{array}{c}1.204 * * * \\
(12.10)\end{array}$ & $\begin{array}{c}1.143 * * * \\
(12.11)\end{array}$ & $\begin{array}{c}1.142 * * * \\
(12.16)\end{array}$ & $\begin{array}{c}1.185 * * * \\
(11.83)\end{array}$ & $\begin{array}{c}1.190 * * * \\
(11.64)\end{array}$ \\
\hline OnTheRun & $\begin{array}{c}0.126^{*} \\
(1.87)\end{array}$ & $\begin{array}{l}0.096 \\
(1.46)\end{array}$ & $\begin{array}{l}0.097 \\
(1.48)\end{array}$ & $\begin{array}{l}0.108 \\
(1.59)\end{array}$ & $\begin{array}{c}0.117 * \\
(1.72)\end{array}$ \\
\hline Year 2007 & $\begin{array}{c}0.648 * * * \\
(23.01)\end{array}$ & $\begin{array}{c}0.664 * * * \\
(23.82)\end{array}$ & $\begin{array}{c}0.664 * * * \\
(23.87)\end{array}$ & $\begin{array}{c}0.649 * * * \\
(23.11)\end{array}$ & $\begin{array}{c}0.643 * * * \\
(22.81)\end{array}$ \\
\hline Year 2008 & $\begin{array}{c}0.572 * * * \\
(11.43)\end{array}$ & $\begin{array}{c}0.561 * * * \\
(11.61)\end{array}$ & $\begin{array}{c}0.561 * * * \\
(11.63)\end{array}$ & $\begin{array}{c}0.567 * * * \\
(11.28)\end{array}$ & $\begin{array}{c}0.581 * * * \\
(11.09)\end{array}$ \\
\hline Year 2009 & $\begin{array}{c}-0.613 * * * \\
(-4.98)\end{array}$ & $\begin{array}{c}-0.677 * * * \\
(-5.80)\end{array}$ & $\begin{array}{c}-0.677 * * * \\
(-5.80)\end{array}$ & $\begin{array}{c}-0.623 * * * \\
(-5.10)\end{array}$ & $\begin{array}{c}-0.592 * * * \\
(-4.71)\end{array}$ \\
\hline Year 2010 & $\begin{array}{c}-1.089 * * * \\
(-8.85)\end{array}$ & $\begin{array}{c}-1.138^{* * *} \\
(-10.06)\end{array}$ & $\begin{array}{c}-1.139 * * * \\
(-10.07)\end{array}$ & $\begin{array}{c}-1.099 * * * \\
(-9.02)\end{array}$ & $\begin{array}{c}-1.046 * * * \\
(-8.43)\end{array}$ \\
\hline Year 2011 & $\begin{array}{c}-0.992 * * * \\
(-8.48)\end{array}$ & $\begin{array}{c}-1.040 * * * \\
(-9.71)\end{array}$ & $\begin{array}{c}-1.042 * * * \\
(-9.74)\end{array}$ & $\begin{array}{c}-1.004 * * * \\
(-8.65)\end{array}$ & $\begin{array}{c}-0.917 * * * \\
(-7.72)\end{array}$ \\
\hline Year 2012 & $\begin{array}{c}-2.004 * * * \\
(-15.77)\end{array}$ & $\begin{array}{c}-2.065^{* * *} \\
(-17.84)\end{array}$ & $\begin{array}{c}-2.068 * * * \\
(-17.92)\end{array}$ & $\begin{array}{c}-2.021 * * * \\
(-15.94)\end{array}$ & $\begin{array}{c}-1.931 * * * \\
(-14.75)\end{array}$ \\
\hline Year 2013 & $\begin{array}{c}-1.900 * * * \\
(-14.48)\end{array}$ & $\begin{array}{c}-1.963 * * * \\
(-16.69)\end{array}$ & $\begin{array}{c}-1.966 * * * \\
(-16.78)\end{array}$ & $\begin{array}{c}-1.921 * * * \\
(-14.62)\end{array}$ & $\begin{array}{c}-1.847 * * * \\
(-13.69)\end{array}$ \\
\hline Year 2014 & $\begin{array}{c}-2.061 * * * \\
(-16.91)\end{array}$ & $\begin{array}{c}-2.128 * * * \\
(-19.80)\end{array}$ & $\begin{array}{c}-2.130 * * * \\
(-19.91)\end{array}$ & $\begin{array}{c}-2.084 * * * \\
(-17.04)\end{array}$ & $\begin{array}{c}-2.021 * * * \\
(-16.22)\end{array}$ \\
\hline Year 2015 & $\begin{array}{c}-2.567 * * * \\
(-23.28)\end{array}$ & $\begin{array}{c}-2.631 * * * \\
(-26.82)\end{array}$ & $\begin{array}{c}-2.631 * * * \\
(-26.92)\end{array}$ & $\begin{array}{c}-2.590 * * * \\
(-23.32)\end{array}$ & $\begin{array}{c}-2.533 * * * \\
(-22.59)\end{array}$ \\
\hline Constant & $\begin{array}{c}0.835 * * * \\
(3.29) \\
\end{array}$ & $\begin{array}{c}1.147 * * * \\
(4.71) \\
\end{array}$ & $\begin{array}{c}1.130 * * * \\
(4.50)\end{array}$ & $\begin{array}{c}0.927 * * * \\
(3.48) \\
\end{array}$ & $\begin{array}{c}1.079 * * * \\
(3.92)\end{array}$ \\
\hline Time and Bond FE & Yes & Yes & Yes & Yes & Yes \\
\hline Observations & 115,574 & 115,574 & 115,574 & 115,574 & 112,851 \\
\hline R-squared & 0.929 & 0.930 & 0.930 & 0.929 & 0.929 \\
\hline
\end{tabular}


A. Table 6 continued Panel B. Displaying Year Fixed Effects

\begin{tabular}{|c|c|c|c|c|c|}
\hline & $\begin{array}{c}1) \\
\text { Yield } \\
\end{array}$ & $\begin{array}{c}(2) \\
\text { Yield } \\
\end{array}$ & $\begin{array}{c}(3) \\
\text { Yield } \\
\end{array}$ & $\begin{array}{c}(4) \\
\text { Yield } \\
\end{array}$ & $\begin{array}{c}(5) \\
\text { Yield } \\
\end{array}$ \\
\hline Utilization & & & $\begin{array}{c}-0.209 * * * \\
(-2.78)\end{array}$ & $\begin{array}{c}-0.318 * * * \\
(-5.38)\end{array}$ & $\begin{array}{c}-0.209 * * * \\
(-2.87)\end{array}$ \\
\hline LogSupply & $\begin{array}{c}0.024^{*} \\
(1.70)\end{array}$ & $\begin{array}{c}0.024^{*} \\
(1.67)\end{array}$ & $\begin{array}{l}-0.000 \\
(-0.02)\end{array}$ & $\begin{array}{l}-0.000 \\
(-0.00)\end{array}$ & $\begin{array}{l}-0.000 \\
(-0.02)\end{array}$ \\
\hline LogDemand & $\begin{array}{c}-0.037 * * \\
(-2.18)\end{array}$ & $\begin{array}{c}-0.037 * * \\
(-2.22)\end{array}$ & & & \\
\hline LogFees & $\begin{array}{c}-0.078 * * * \\
(-5.78)\end{array}$ & $\begin{array}{c}-0.078 * * * \\
(-5.74)\end{array}$ & $\begin{array}{c}-0.089 * * * \\
(-6.71)\end{array}$ & $\begin{array}{c}-0.128 * * * \\
(-7.94)\end{array}$ & $\begin{array}{c}-0.124 * * * \\
(-7.83)\end{array}$ \\
\hline Longmat & $\begin{array}{c}0.310^{* * *} \\
(3.38)\end{array}$ & $\begin{array}{c}0.313^{* *} \\
(2.57)\end{array}$ & $\begin{array}{c}0.517 * * * \\
(5.49)\end{array}$ & $\begin{array}{l}-0.199 \\
(-1.51)\end{array}$ & $\begin{array}{l}0.029 \\
(0.26)\end{array}$ \\
\hline LogDemand*Longmat & & $\begin{array}{l}-0.000 \\
(-0.03)\end{array}$ & & & \\
\hline Uti*Longmat & & & $\begin{array}{c}-0.594 * * * \\
(-3.71)\end{array}$ & & $\begin{array}{c}-0.491 * * * \\
(-3.13)\end{array}$ \\
\hline LogFees*Longmat & & & & $\begin{array}{c}0.197 * * * \\
(5.75)\end{array}$ & $\begin{array}{c}0.174 * * * \\
(5.44)\end{array}$ \\
\hline LogTTM & $\begin{array}{c}1.199 * * * \\
(11.85)\end{array}$ & $\begin{array}{c}1.199 * * * \\
(11.72)\end{array}$ & $\begin{array}{c}1.079 * * * \\
(10.96)\end{array}$ & $\begin{array}{c}1.064 * * * \\
(11.16)\end{array}$ & $\begin{array}{c}1.014 * * * \\
(10.37)\end{array}$ \\
\hline OnTheRun & $\begin{array}{l}0.098 \\
(1.44)\end{array}$ & $\begin{array}{l}0.098 \\
(1.44)\end{array}$ & $\begin{array}{l}0.090 \\
(1.45)\end{array}$ & $\begin{array}{l}0.075 \\
(1.17)\end{array}$ & $\begin{array}{l}0.080 \\
(1.30)\end{array}$ \\
\hline Year 2007 & $\begin{array}{c}0.647 * * * \\
(23.50)\end{array}$ & $\begin{array}{c}0.647 * * * \\
(23.50)\end{array}$ & $\begin{array}{c}0.654 * * * \\
(25.20)\end{array}$ & $\begin{array}{c}0.640 * * * \\
(23.49)\end{array}$ & $\begin{array}{c}0.635^{* * * *} \\
(24.14)\end{array}$ \\
\hline Year 2008 & $\begin{array}{c}0.588 * * * \\
(11.35)\end{array}$ & $\begin{array}{c}0.588 * * * \\
(11.29)\end{array}$ & $\begin{array}{c}0.559 * * * \\
(10.55)\end{array}$ & $\begin{array}{c}0.542 * * * \\
(10.59)\end{array}$ & $\begin{array}{c}0.527 * * * \\
(9.93)\end{array}$ \\
\hline Year 2009 & $\begin{array}{c}-0.585^{* * *} * \\
(-4.66)\end{array}$ & $\begin{array}{c}-0.585 * * * \\
(-4.61)\end{array}$ & $\begin{array}{c}-0.694 * * * \\
(-5.52)\end{array}$ & $\begin{array}{c}-0.697 * * * \\
(-5.74)\end{array}$ & $\begin{array}{c}-0.733 * * * \\
(-5.86)\end{array}$ \\
\hline Year 2010 & $\begin{array}{c}-1.037 * * * \\
(-8.40)\end{array}$ & $\begin{array}{c}-1.037 * * * \\
(-8.28)\end{array}$ & $\begin{array}{c}-1.155 * * * \\
(-9.44)\end{array}$ & $\begin{array}{c}-1.157 * * * \\
(-9.95)\end{array}$ & $\begin{array}{c}-1.214 * * * \\
(-10.02)\end{array}$ \\
\hline Year 2011 & $\begin{array}{c}-0.905 * * * \\
(-7.70)\end{array}$ & $\begin{array}{c}-0.905 * * * \\
(-7.52)\end{array}$ & $\begin{array}{c}-1.028 * * * \\
(-8.75)\end{array}$ & $\begin{array}{c}-1.041 * * * \\
(-9.48)\end{array}$ & $\begin{array}{c}-1.104 * * * \\
(-9.57)\end{array}$ \\
\hline Year 2012 & $\begin{array}{c}-1.916^{* * *} \\
(-14.82)\end{array}$ & $\begin{array}{c}-1.916^{* * *} \\
(-14.47)\end{array}$ & $\begin{array}{c}-2.072 * * * \\
(-16.39)\end{array}$ & $\begin{array}{c}-2.079 * * * \\
(-17.43)\end{array}$ & $\begin{array}{c}-2.160 * * * \\
(-17.32)\end{array}$ \\
\hline Year 2013 & $\begin{array}{c}-1.829 * * * \\
(-13.77)\end{array}$ & $\begin{array}{c}-1.830 * * * \\
(-13.37)\end{array}$ & $\begin{array}{c}-2.014 * * * \\
(-15.69)\end{array}$ & $\begin{array}{c}-2.003 * * * \\
(-16.50)\end{array}$ & $\begin{array}{c}-2.106 * * * \\
(-16.40)\end{array}$ \\
\hline Year 2014 & $\begin{array}{c}-1.996 * * * \\
(-16.13)\end{array}$ & $\begin{array}{c}-1.996 * * * \\
(-15.53)\end{array}$ & $\begin{array}{c}-2.191 * * * \\
(-18.08)\end{array}$ & $\begin{array}{c}-2.186^{* * * *} \\
(-19.43)\end{array}$ & $\begin{array}{c}-2.295 * * * \\
(-18.85)\end{array}$ \\
\hline Year 2015 & $\begin{array}{c}-2.507 * * * \\
(-22.44)\end{array}$ & $\begin{array}{c}-2.507 * * * \\
(-21.65)\end{array}$ & $\begin{array}{c}-2.698 * * * \\
(-24.70)\end{array}$ & $\begin{array}{c}-2.701 * * * \\
(-26.23)\end{array}$ & $\begin{array}{c}-2.811 * * * \\
(-25.31)\end{array}$ \\
\hline Constant & $\begin{array}{c}0.984 * * * \\
(3.55) \\
\end{array}$ & $\begin{array}{c}0.984 * * * \\
(3.57) \\
\end{array}$ & $\begin{array}{c}1.382 * * * \\
(4.89)\end{array}$ & $\begin{array}{c}1.565 * * * \\
(5.99)\end{array}$ & $\begin{array}{c}1.653 * * * \\
(6.03)\end{array}$ \\
\hline Time and Bond FE & Yes & Yes & Yes & Yes & Yes \\
\hline Observations & 112,851 & 112,851 & 112,851 & 112,851 & 112,851 \\
\hline R-squared & 0.930 & 0.930 & 0.932 & 0.932 & 0.932 \\
\hline
\end{tabular}


A. Table 7. Lending Fee Dynamics With Endogenous Demand/Supply Shocks in the Securities Lending Market Full specification Displaying Year Fixed Effects

\begin{tabular}{|c|c|c|c|c|c|c|}
\hline & $\begin{array}{c}(1) \\
\text { LogFees }\end{array}$ & $\begin{array}{c}(2) \\
\text { LogFees } \\
\end{array}$ & $\begin{array}{c}(3) \\
\text { LogFees } \\
\end{array}$ & $\begin{array}{c}(4) \\
\text { LogFees }\end{array}$ & $\begin{array}{c}(5) \\
\text { LogFees }\end{array}$ & $\begin{array}{c}(6) \\
\text { LogFees }\end{array}$ \\
\hline $\operatorname{LogDemand}_{-3}$ & $\begin{array}{l}0.019 \\
(1.63)\end{array}$ & $\begin{array}{l}0.019^{*} \\
(1.69)\end{array}$ & $\begin{array}{l}0.018 \\
(1.52)\end{array}$ & $\begin{array}{l}0.019^{*} \\
(1.68)\end{array}$ & $\begin{array}{c}0.020^{*} \\
(1.75)\end{array}$ & $\begin{array}{l}0.019 \\
(1.60)\end{array}$ \\
\hline LogSupply $_{-3}$ & $\begin{array}{c}-0.028 * * * \\
(-2.89)\end{array}$ & $\begin{array}{c}-0.028 * * * \\
(-2.91)\end{array}$ & $\begin{array}{c}-0.029 * * * \\
(-3.11)\end{array}$ & $\begin{array}{c}-0.028 * * * \\
(-2.94)\end{array}$ & $\begin{array}{c}-0.028 * * * \\
(-2.96)\end{array}$ & $\begin{array}{c}-0.030 * * * \\
(-3.21)\end{array}$ \\
\hline DemIncrease $_{-1}$ & $\begin{array}{c}0.036^{* *} \\
(2.20)\end{array}$ & $\begin{array}{c}0.038^{* *} \\
(2.23)\end{array}$ & $\begin{array}{c}0.038^{* *} \\
(2.22)\end{array}$ & $\begin{array}{c}0.036^{* *} \\
(2.50)\end{array}$ & $\begin{array}{c}0.039 * * \\
(2.58)\end{array}$ & $\begin{array}{c}0.038^{* *} \\
(2.54)\end{array}$ \\
\hline DemIncrease $_{-2}$ & & $\begin{array}{c}0.024 * \\
(1.78)\end{array}$ & $\begin{array}{l}0.020 \\
(1.34)\end{array}$ & & $\begin{array}{c}0.028 * * \\
(2.02)\end{array}$ & $\begin{array}{l}0.025 \\
(1.59)\end{array}$ \\
\hline DemIncrease $_{-3}$ & & & $\begin{array}{l}-0.026 \\
(-1.53)\end{array}$ & & & $\begin{array}{l}-0.018 \\
(-0.95)\end{array}$ \\
\hline Longmat & & & & $\begin{array}{l}0.158 \\
(1.47)\end{array}$ & $\begin{array}{l}0.159 \\
(1.47)\end{array}$ & $\begin{array}{l}0.167 \\
(1.53)\end{array}$ \\
\hline DemIncrease $_{-1} *$ Longmat & & & & $\begin{array}{l}-0.004 \\
(-0.07)\end{array}$ & $\begin{array}{l}-0.005 \\
(-0.10)\end{array}$ & $\begin{array}{l}-0.002 \\
(-0.04)\end{array}$ \\
\hline DemIncrease $_{-2} *$ Longmat & & & & & $\begin{array}{l}-0.019 \\
(-0.49)\end{array}$ & $\begin{array}{l}-0.022 \\
(-0.54)\end{array}$ \\
\hline DemIncrease $_{-3} *$ Longmat & & & & & & $\begin{array}{l}-0.038 \\
(-1.15)\end{array}$ \\
\hline LogTTM & $\begin{array}{l}0.043 \\
(0.46)\end{array}$ & $\begin{array}{l}0.041 \\
(0.44)\end{array}$ & $\begin{array}{l}0.043 \\
(0.46)\end{array}$ & $\begin{array}{l}0.047 \\
(0.50)\end{array}$ & $\begin{array}{l}0.045 \\
(0.48)\end{array}$ & $\begin{array}{l}0.044 \\
(0.47)\end{array}$ \\
\hline OnTheRun & $\begin{array}{c}0.089 * \\
(1.66)\end{array}$ & $\begin{array}{l}0.089 \\
(1.65)\end{array}$ & $\begin{array}{l}0.088 \\
(1.63)\end{array}$ & $\begin{array}{l}0.080 \\
(1.55)\end{array}$ & $\begin{array}{l}0.080 \\
(1.54)\end{array}$ & $\begin{array}{l}0.077 \\
(1.49)\end{array}$ \\
\hline Year 2007 & $\begin{array}{c}-0.142 * * * \\
(-4.82)\end{array}$ & $\begin{array}{c}-0.142 * * * \\
(-4.81)\end{array}$ & $\begin{array}{c}-0.142 * * * \\
(-4.80)\end{array}$ & $\begin{array}{c}-0.140^{* * * *} \\
(-4.71)\end{array}$ & $\begin{array}{c}-0.140 * * * \\
(-4.70)\end{array}$ & $\begin{array}{c}-0.140 * * * \\
(-4.70)\end{array}$ \\
\hline Year 2008 & $\begin{array}{c}0.134^{*} \\
(1.90)\end{array}$ & $\begin{array}{c}0.134^{*} \\
(1.90)\end{array}$ & $\begin{array}{l}0.134^{*} \\
(1.90)\end{array}$ & $\begin{array}{c}0.137^{*} \\
(1.93)\end{array}$ & $\begin{array}{c}0.137^{*} \\
(1.92)\end{array}$ & $\begin{array}{l}0.136^{*} \\
(1.92)\end{array}$ \\
\hline Year 2009 & $\begin{array}{c}0.425 * * * \\
(6.16)\end{array}$ & $\begin{array}{c}0.425 * * * \\
(6.18)\end{array}$ & $\begin{array}{c}0.424 * * * \\
(6.18)\end{array}$ & $\begin{array}{c}0.428 * * * \\
(6.17)\end{array}$ & $\begin{array}{c}0.428 * * * \\
(6.18)\end{array}$ & $\begin{array}{c}0.426^{* * *} \\
(6.18)\end{array}$ \\
\hline Year 2010 & $\begin{array}{c}0.637 * * * \\
(8.22)\end{array}$ & $\begin{array}{c}0.638 * * * \\
(8.22)\end{array}$ & $\begin{array}{c}0.636 * * * \\
(8.21)\end{array}$ & $\begin{array}{c}0.641 * * * \\
(8.27)\end{array}$ & $\begin{array}{c}0.642 * * * \\
(8.27)\end{array}$ & $\begin{array}{c}0.639 * * * \\
(8.26)\end{array}$ \\
\hline Year 2011 & $\begin{array}{c}0.962 * * * \\
(10.34)\end{array}$ & $\begin{array}{c}0.963 * * * \\
(10.36)\end{array}$ & $\begin{array}{c}0.962 * * * \\
(10.36)\end{array}$ & $\begin{array}{c}0.967 * * * \\
(10.35)\end{array}$ & $\begin{array}{c}0.968 * * * \\
(10.35)\end{array}$ & $\begin{array}{c}0.966^{* * *} \\
(10.34)\end{array}$ \\
\hline Year 2012 & $\begin{array}{c}0.980 * * * \\
(9.38)\end{array}$ & $\begin{array}{c}0.983 * * * \\
(9.40)\end{array}$ & $\begin{array}{c}0.981 * * * \\
(9.40)\end{array}$ & $\begin{array}{c}0.987 * * * \\
(9.41)\end{array}$ & $\begin{array}{c}0.988 * * * \\
(9.41)\end{array}$ & $\begin{array}{c}0.985 * * * \\
(9.39)\end{array}$ \\
\hline Year 2013 & $\begin{array}{c}0.767 * * * \\
(6.23)\end{array}$ & $\begin{array}{c}0.769 * * * \\
(6.26)\end{array}$ & $\begin{array}{c}0.767 * * * \\
(6.25)\end{array}$ & $\begin{array}{c}0.775 * * * \\
(6.27)\end{array}$ & $\begin{array}{c}0.776^{* * * *} \\
(6.28)\end{array}$ & $\begin{array}{c}0.772 * * * \\
(6.25)\end{array}$ \\
\hline Year 2014 & $\begin{array}{c}0.716^{* * *} \\
(5.19)\end{array}$ & $\begin{array}{c}0.718^{* * *} \\
(5.21)\end{array}$ & $\begin{array}{c}0.716^{* * *} \\
(5.20)\end{array}$ & $\begin{array}{c}0.728 * * * \\
(5.22)\end{array}$ & $\begin{array}{c}0.729 * * * \\
(5.22)\end{array}$ & $\begin{array}{c}0.725^{* * *} \\
(5.19)\end{array}$ \\
\hline Year 2015 & $\begin{array}{c}0.802 * * * \\
(5.53)\end{array}$ & $\begin{array}{c}0.804 * * * \\
(5.55)\end{array}$ & $\begin{array}{c}0.802 * * * \\
(5.54)\end{array}$ & $\begin{array}{c}0.815 * * * \\
(5.54)\end{array}$ & $\begin{array}{c}0.815^{* * *} \\
(5.54)\end{array}$ & $\begin{array}{c}0.810^{* * *} \\
(5.51)\end{array}$ \\
\hline Constant & $\begin{array}{c}1.715^{* * * *} \\
(7.23) \\
\end{array}$ & $\begin{array}{c}1.710 * * * \\
(7.22)\end{array}$ & $\begin{array}{c}1.735^{* * *} \\
(7.33) \\
\end{array}$ & $\begin{array}{c}1.666^{* * * *} \\
(6.78) \\
\end{array}$ & $\begin{array}{c}1.664 * * * \\
(6.78) \\
\end{array}$ & $\begin{array}{c}1.693 * * * \\
(6.93) \\
\end{array}$ \\
\hline Time and Bond FE & Yes & Yes & Yes & Yes & Yes & Yes \\
\hline Observations & 112,667 & 112,667 & 112,667 & 112,667 & 112,667 & 112,667 \\
\hline R-squared & 0.344 & 0.344 & 0.344 & 0.344 & 0.344 & 0.344 \\
\hline
\end{tabular}


Appendix B. continued

A. Table 7 continued. Displaying Year Fixed Effects

\begin{tabular}{|c|c|c|c|c|}
\hline & $\begin{array}{c}(1) \\
\text { LogFees }\end{array}$ & $\begin{array}{c}(2) \\
\text { LogFees }\end{array}$ & $\begin{array}{c}(3) \\
\text { LogFees }\end{array}$ & $\begin{array}{c}(4) \\
\text { LogFees }\end{array}$ \\
\hline LogSupply & $\begin{array}{c}-0.028 * * * \\
(-4.05)\end{array}$ & $\begin{array}{c}-0.028 * * * \\
(-4.03)\end{array}$ & $\begin{array}{c}-0.028 * * * \\
(-4.03)\end{array}$ & $\begin{array}{c}-0.028 * * * \\
(-4.03)\end{array}$ \\
\hline Repwind & $\begin{array}{c}0.021 * \\
(1.95)\end{array}$ & $\begin{array}{c}0.022 * * \\
(2.03)\end{array}$ & $\begin{array}{c}0.022 * * \\
(2.03)\end{array}$ & $\begin{array}{c}0.022 * * \\
(2.04)\end{array}$ \\
\hline LogSupply $_{-5}$ & $\begin{array}{c}-0.022^{* *} \\
(-2.51)\end{array}$ & $\begin{array}{c}-0.023 * * \\
(-2.57)\end{array}$ & $\begin{array}{c}-0.023 * * \\
(-2.57)\end{array}$ & $\begin{array}{c}-0.023 * * \\
(-2.58)\end{array}$ \\
\hline LogDemand $_{-5}$ & $\begin{array}{c}0.098 * * * \\
(4.63)\end{array}$ & $\begin{array}{c}0.080 * * * \\
(3.26)\end{array}$ & $\begin{array}{l}0.024 \\
(0.61)\end{array}$ & $\begin{array}{l}0.052 \\
(1.08)\end{array}$ \\
\hline Longmat & & $\begin{array}{l}0.165 \\
(1.63)\end{array}$ & $\begin{array}{l}0.165 \\
(1.63)\end{array}$ & $\begin{array}{l}0.165 \\
(1.63)\end{array}$ \\
\hline Repwind*Longmat & & $\begin{array}{c}0.080 * \\
(1.69)\end{array}$ & $\begin{array}{c}0.079 * \\
(1.67)\end{array}$ & $\begin{array}{l}-0.050 \\
(-0.45)\end{array}$ \\
\hline Aft 2010 & & & $\begin{array}{c}0.090^{*} \\
(1.83)\end{array}$ & $\begin{array}{l}0.045 \\
(0.78)\end{array}$ \\
\hline Aft $2010 *$ Repwind & & & $\begin{array}{c}0.820 * * * \\
(5.55)\end{array}$ & $\begin{array}{c}0.818 * * * \\
(5.57)\end{array}$ \\
\hline Aft $2010 *$ Repwind*Longmat & & & & $\begin{array}{l}0.204 \\
(1.39)\end{array}$ \\
\hline LogTTM & $\begin{array}{l}0.051 \\
(0.54)\end{array}$ & $\begin{array}{l}0.055 \\
(0.59)\end{array}$ & $\begin{array}{l}0.055 \\
(0.59)\end{array}$ & $\begin{array}{l}0.054 \\
(0.58)\end{array}$ \\
\hline OnTheRun & $\begin{array}{l}0.084 \\
(1.54)\end{array}$ & $\begin{array}{l}0.075 \\
(1.42)\end{array}$ & $\begin{array}{l}0.075 \\
(1.42)\end{array}$ & $\begin{array}{l}0.075 \\
(1.42)\end{array}$ \\
\hline Year 2007 & $\begin{array}{c}-0.138 * * * \\
(-4.68)\end{array}$ & $\begin{array}{c}-0.136 * * * \\
(-4.58)\end{array}$ & $\begin{array}{c}-0.137 * * * \\
(-4.61)\end{array}$ & $\begin{array}{c}-0.137 * * * \\
(-4.62)\end{array}$ \\
\hline Year 2008 & $\begin{array}{c}0.141^{*} \\
(1.97)\end{array}$ & $\begin{array}{c}0.143^{* *} \\
(2.01)\end{array}$ & $\begin{array}{c}0.143 * * \\
(2.00)\end{array}$ & $\begin{array}{c}0.142 * * \\
(1.99)\end{array}$ \\
\hline Year 2009 & $\begin{array}{c}0.424 * * * \\
(6.18)\end{array}$ & $\begin{array}{c}0.427 * * * \\
(6.17)\end{array}$ & $\begin{array}{c}0.427 * * * \\
(6.17)\end{array}$ & $\begin{array}{c}0.426 * * * \\
(6.16)\end{array}$ \\
\hline Year 2010 & $\begin{array}{c}0.638 * * * \\
(8.13)\end{array}$ & $\begin{array}{c}0.642 * * * \\
(8.14)\end{array}$ & $\begin{array}{c}-0.180 * \\
(-1.84)\end{array}$ & $\begin{array}{c}-0.179^{*} \\
(-1.84)\end{array}$ \\
\hline Year 2011 & $\begin{array}{c}0.972 * * * \\
(10.42)\end{array}$ & $\begin{array}{c}0.978 * * * \\
(10.40)\end{array}$ & $\begin{array}{c}0.155^{* *} \\
(2.04)\end{array}$ & $\begin{array}{c}0.156^{* *} \\
(2.05)\end{array}$ \\
\hline Year 2012 & $\begin{array}{c}0.994 * * * \\
(9.47)\end{array}$ & $\begin{array}{c}1.001 * * * \\
(9.47)\end{array}$ & $\begin{array}{c}0.179 * * * \\
(2.81)\end{array}$ & $\begin{array}{c}0.180 * * * \\
(2.82)\end{array}$ \\
\hline Year 2013 & $\begin{array}{c}0.781 * * * \\
(6.34)\end{array}$ & $\begin{array}{c}0.789 * * * \\
(6.38)\end{array}$ & $\begin{array}{l}-0.033 \\
(-0.57)\end{array}$ & $\begin{array}{l}-0.032 \\
(-0.57)\end{array}$ \\
\hline Year 2014 & $\begin{array}{c}0.727 * * * \\
(5.27)\end{array}$ & $\begin{array}{c}0.740 * * * \\
(5.30)\end{array}$ & $\begin{array}{c}-0.082 * * \\
(-2.19)\end{array}$ & $\begin{array}{c}-0.082 * * \\
(-2.18)\end{array}$ \\
\hline Year 2015 & $\begin{array}{c}0.808 * * * \\
(5.56)\end{array}$ & $\begin{array}{c}0.822 * * * \\
(5.55)\end{array}$ & - & - \\
\hline Constant & $\begin{array}{c}1.852 * * * \\
(7.81)\end{array}$ & $\begin{array}{c}1.799 * * * \\
(7.30)\end{array}$ & $\begin{array}{c}1.800 * * * \\
(7.31)\end{array}$ & $\begin{array}{c}1.804 * * * \\
(7.35) \\
\end{array}$ \\
\hline $\begin{array}{l}\text { Time and Bond FE } \\
\text { Observations } \\
\text { R-squared }\end{array}$ & $\begin{array}{c}\text { Yes } \\
112,479 \\
0.347\end{array}$ & $\begin{array}{c}\text { Yes } \\
112,479 \\
0.347\end{array}$ & $\begin{array}{c}\text { Yes } \\
112,479 \\
0.347\end{array}$ & $\begin{array}{c}\text { Yes } \\
112,479 \\
0.347\end{array}$ \\
\hline
\end{tabular}


A. Table 8. Lending Fee Dynamics with Expected Supply and Demand Changes with Full Specification, Displaying Year Fixed Effects

\begin{tabular}{|c|c|c|c|c|c|c|c|}
\hline & $\begin{array}{c}(1) \\
\text { Feespread }\end{array}$ & $\begin{array}{c}(2) \\
\text { Feespread }\end{array}$ & $\begin{array}{c}(3) \\
\text { Feespread }\end{array}$ & $\begin{array}{c}(4) \\
\text { Feespread }\end{array}$ & $\begin{array}{c}\text { (5) } \\
\text { Feespread }\end{array}$ & $\begin{array}{c}(6) \\
\text { Feespread }\end{array}$ & $\begin{array}{c}(7) \\
\text { Feespread }\end{array}$ \\
\hline LogSupply & $\begin{array}{c}0.716^{* * *} \\
(12.32)\end{array}$ & $\begin{array}{c}0.716^{* * *} \\
(12.32)\end{array}$ & $\begin{array}{c}0.716 * * * \\
(12.47)\end{array}$ & $\begin{array}{c}0.717 * * * \\
(12.35)\end{array}$ & $\begin{array}{c}0.717 * * * \\
(12.50)\end{array}$ & $\begin{array}{c}0.619 * * * \\
(7.76)\end{array}$ & $\begin{array}{c}0.621 * * * \\
(7.82)\end{array}$ \\
\hline Repwind & $\begin{array}{c}0.136 * * * \\
(4.75)\end{array}$ & $\begin{array}{c}0.135 * * * \\
(4.77)\end{array}$ & $\begin{array}{c}0.135 * * * \\
(4.79)\end{array}$ & $\begin{array}{c}0.131 * * * \\
(4.67)\end{array}$ & $\begin{array}{c}0.131 * * * \\
(4.70)\end{array}$ & $\begin{array}{c}0.149 * * * \\
(5.20)\end{array}$ & $\begin{array}{c}0.153 * * * \\
(5.50)\end{array}$ \\
\hline LogFees & $\begin{array}{c}0.141 * * * \\
(5.86)\end{array}$ & $\begin{array}{c}0.141 * * * \\
(5.84)\end{array}$ & $\begin{array}{c}0.141 * * * \\
(5.85)\end{array}$ & $\begin{array}{c}0.124 * * * \\
(4.14)\end{array}$ & $\begin{array}{c}0.124 * * * \\
(4.16)\end{array}$ & $\begin{array}{c}0.146 * * * \\
(6.16)\end{array}$ & $\begin{array}{c}0.146^{* * * *} \\
(6.14)\end{array}$ \\
\hline Utilization & $\begin{array}{c}-0.607 * * * \\
(-3.52)\end{array}$ & $\begin{array}{c}-0.607 * * * \\
(-3.52)\end{array}$ & $\begin{array}{c}-0.598 * * * \\
(-3.20)\end{array}$ & $\begin{array}{c}-0.595 * * * \\
(-3.47)\end{array}$ & $\begin{array}{c}-0.593 * * * \\
(-3.19)\end{array}$ & & \\
\hline Longmat & & $\begin{array}{l}0.071 \\
(0.68)\end{array}$ & $\begin{array}{l}0.086 \\
(0.49)\end{array}$ & $\begin{array}{l}-0.154 \\
(-0.71)\end{array}$ & $\begin{array}{l}-0.151 \\
(-0.59)\end{array}$ & $\begin{array}{l}0.070 \\
(0.63)\end{array}$ & $\begin{array}{l}-0.354 \\
(-0.51)\end{array}$ \\
\hline Uti*Longmat & & & $\begin{array}{l}-0.042 \\
(-0.11)\end{array}$ & & $\begin{array}{l}-0.008 \\
(-0.02)\end{array}$ & & \\
\hline LogFees*Longmat & & & & $\begin{array}{l}0.085 \\
(1.19)\end{array}$ & $\begin{array}{l}0.085 \\
(1.20)\end{array}$ & & \\
\hline LogDemand & & & & & & $\begin{array}{l}0.091 * \\
(1.77)\end{array}$ & $\begin{array}{l}0.075 \\
(1.39)\end{array}$ \\
\hline LogDem*Longmat & & & & & & & $\begin{array}{l}0.066 \\
(0.64)\end{array}$ \\
\hline LogTTM & $\begin{array}{c}-0.518 * * * \\
(-4.81)\end{array}$ & $\begin{array}{c}-0.516^{* * *} \\
(-4.78)\end{array}$ & $\begin{array}{c}-0.522 * * * \\
(-4.36)\end{array}$ & $\begin{array}{c}-0.554 * * * \\
(-4.77)\end{array}$ & $\begin{array}{c}-0.555 * * * \\
(-4.40)\end{array}$ & $\begin{array}{c}-0.353^{* * * *} \\
(-3.27)\end{array}$ & $\begin{array}{c}-0.319 * * \\
(-2.52)\end{array}$ \\
\hline OnTheRun & $\begin{array}{l}0.003 \\
(0.04)\end{array}$ & $\begin{array}{l}-0.001 \\
(-0.02)\end{array}$ & $\begin{array}{l}-0.001 \\
(-0.01)\end{array}$ & $\begin{array}{l}-0.005 \\
(-0.06)\end{array}$ & $\begin{array}{l}-0.005 \\
(-0.06)\end{array}$ & $\begin{array}{l}0.059 \\
(0.70)\end{array}$ & $\begin{array}{l}0.058 \\
(0.69)\end{array}$ \\
\hline Year 2007 & $\begin{array}{l}0.026 \\
(0.37)\end{array}$ & $\begin{array}{l}0.027 \\
(0.38)\end{array}$ & $\begin{array}{l}0.026 \\
(0.38)\end{array}$ & $\begin{array}{l}0.017 \\
(0.25)\end{array}$ & $\begin{array}{l}0.017 \\
(0.25)\end{array}$ & $\begin{array}{l}0.001 \\
(0.01)\end{array}$ & $\begin{array}{l}0.008 \\
(0.11)\end{array}$ \\
\hline Year 2008 & $\begin{array}{c}0.235 * * \\
(2.46)\end{array}$ & $\begin{array}{c}0.236 * * \\
(2.47)\end{array}$ & $\begin{array}{c}0.234 * * \\
(2.50)\end{array}$ & $\begin{array}{c}0.219 * * \\
(2.22)\end{array}$ & $\begin{array}{c}0.218 * * \\
(2.26)\end{array}$ & $\begin{array}{c}0.280 * * * \\
(2.81)\end{array}$ & $\begin{array}{c}0.294 * * * \\
(2.85)\end{array}$ \\
\hline Year 2009 & $\begin{array}{l}0.010 \\
(0.08)\end{array}$ & $\begin{array}{l}0.012 \\
(0.09)\end{array}$ & $\begin{array}{l}0.007 \\
(0.05)\end{array}$ & $\begin{array}{l}-0.011 \\
(-0.09)\end{array}$ & $\begin{array}{l}-0.012 \\
(-0.09)\end{array}$ & $\begin{array}{l}0.179 \\
(1.47)\end{array}$ & $\begin{array}{l}0.205 \\
(1.51)\end{array}$ \\
\hline Year 2010 & $\begin{array}{c}-0.576 * * * \\
(-4.88)\end{array}$ & $\begin{array}{c}-0.574 * * * \\
(-4.85)\end{array}$ & $\begin{array}{c}-0.581 * * * \\
(-4.26)\end{array}$ & $\begin{array}{c}-0.610 * * * \\
(-4.75)\end{array}$ & $\begin{array}{c}-0.611 * * * \\
(-4.26)\end{array}$ & $\begin{array}{c}-0.445^{* * * *} \\
(-3.43)\end{array}$ & $\begin{array}{c}-0.408 * * * \\
(-2.70)\end{array}$ \\
\hline Year 2011 & $\begin{array}{c}-0.363 * * \\
(-2.54)\end{array}$ & $\begin{array}{c}-0.361 * * \\
(-2.52)\end{array}$ & $\begin{array}{c}-0.369 * * \\
(-2.21)\end{array}$ & $\begin{array}{c}-0.406 * * \\
(-2.51)\end{array}$ & $\begin{array}{c}-0.408 * * \\
(-2.26)\end{array}$ & $\begin{array}{l}-0.221 \\
(-1.43)\end{array}$ & $\begin{array}{l}-0.180 \\
(-1.01)\end{array}$ \\
\hline Year 2012 & $\begin{array}{c}-0.615 * * * \\
(-4.24)\end{array}$ & $\begin{array}{c}-0.612 * * * \\
(-4.21)\end{array}$ & $\begin{array}{c}-0.621 * * * \\
(-3.53)\end{array}$ & $\begin{array}{c}-0.665 * * * \\
(-4.01)\end{array}$ & $\begin{array}{c}-0.667 * * * \\
(-3.50)\end{array}$ & $\begin{array}{c}-0.423^{* *} \\
(-2.58)\end{array}$ & $\begin{array}{c}-0.371 * \\
(-1.89)\end{array}$ \\
\hline Year 2013 & $\begin{array}{c}-0.940 * * * \\
(-5.71)\end{array}$ & $\begin{array}{c}-0.936 * * * \\
(-5.66)\end{array}$ & $\begin{array}{c}-0.947 * * * \\
(-4.78)\end{array}$ & $\begin{array}{c}-0.994 * * * \\
(-5.36)\end{array}$ & $\begin{array}{c}-0.996 * * * \\
(-4.69)\end{array}$ & $\begin{array}{c}-0.735^{* * *} \\
(-4.01)\end{array}$ & $\begin{array}{c}-0.673 * * * \\
(-3.09)\end{array}$ \\
\hline Year 2014 & $\begin{array}{c}-0.974 * * * \\
(-5.66)\end{array}$ & $\begin{array}{c}-0.969 * * * \\
(-5.56)\end{array}$ & $\begin{array}{c}-0.981 * * * \\
(-4.70)\end{array}$ & $\begin{array}{c}-1.034 * * * \\
(-5.33)\end{array}$ & $\begin{array}{c}-1.036 * * * \\
(-4.65)\end{array}$ & $\begin{array}{c}-0.761 * * * \\
(-3.90)\end{array}$ & $\begin{array}{c}-0.691 * * * \\
(-2.93)\end{array}$ \\
\hline Year 2015 & $\begin{array}{c}-0.732 * * * \\
(-4.14)\end{array}$ & $\begin{array}{c}-0.726 * * * \\
(-4.07)\end{array}$ & $\begin{array}{c}-0.738 * * * \\
(-3.36)\end{array}$ & $\begin{array}{c}-0.795 * * * \\
(-3.97)\end{array}$ & $\begin{array}{c}-0.797 * * * \\
(-3.40)\end{array}$ & $\begin{array}{c}-0.537 * * * \\
(-2.75)\end{array}$ & $\begin{array}{c}-0.469 * * \\
(-2.05)\end{array}$ \\
\hline Constant & $\begin{array}{l}-0.544 \\
(-1.14) \\
\end{array}$ & $\begin{array}{l}-0.566 \\
(-1.17) \\
\end{array}$ & $\begin{array}{l}-0.554 \\
(-1.04) \\
\end{array}$ & $\begin{array}{l}-0.427 \\
(-0.83) \\
\end{array}$ & $\begin{array}{l}-0.425 \\
(-0.77) \\
\end{array}$ & $\begin{array}{c}-1.229 * * \\
(-2.28) \\
\end{array}$ & $\begin{array}{c}-1.232 * * \\
(-2.37) \\
\end{array}$ \\
\hline Time and Bond FE & Yes & Yes & Yes & Yes & Yes & Yes & Yes \\
\hline Observations & 104,505 & 104,505 & 104,505 & 104,505 & 104,505 & 104,505 & 104,505 \\
\hline $\mathrm{R}$-squared & 0.461 & 0.461 & 0.461 & 0.461 & 0.461 & 0.454 & 0.454 \\
\hline
\end{tabular}




\section{Appendix C. Example of Pension Funds Engagement in Securities Lending with Prime Brokers/Agents}

CalPERS Securities Lending Program, 2011 Annual Financial Report ${ }^{18}$

"The State Constitution and CalPERS Board policies permit CalPERS to use investments of the PERF to enter into securities lending transactions, collateralized loans of securities to broker-dealers and other entities with a simultaneous agreement to return the collateral for the same securities in the future. CalPERS has contracted with eSecLending LLC (eSec), State Street Bank \& Trust (SSB), and Goldman Sachs Agency Lending as thirdparty securities lending agents to loan domestic and international equity and debt securities. Additionally, CalPERS contracts with eSecLending as an administrative agent for CalPERS principal borrowers. CalPERS receives both cash and non-cash (i.e., securities) collateral.

Domestic and international securities are collateralized for cash at 102 percent and 105 percent, respectively, of the loaned securities market value. Management believes CalPERS has minimized credit risk exposure to borrowers by requiring the borrower to provide collateralization greater than 100 percent of the market value of the securities loaned. Securities borrowed are required to be overcollateralized by 2 percent (domestic) and 5 percent (international), and all borrowed securities are priced end of day. Based on a borrower's aggregate end of day market value, a wire is sent or delivered to maintain the proper overcollateralization level. On June 30 , 2011 , the fair value of the securities on loan was approximately $\$ 19.8$ billion. The CalPERS Fixed Income Unit manages the securities lending activity on behalf of PERF assets in individual funds and in unitized equity and debt security pools. All securities lending activities, whether individual PERF funds or unitized pools, are subject to the constraints set forth in CalPERS Securities Lending Policy.

CalPERS' policy is to invest the cash collateral in short-term, high-credit quality fixed income securities. Currently, SSB, eSec, and CalPERS manage the cash collateral. The re-invested cash collateral is reported in the financial statements at fair value, except for the re-invested cash collateral held by eSec. The re-invested cash collateral held by eSec is reported at cost, which approximates fair value. As of June 30, 2011, the cash collateral invested by SSB, eSec, CalPERS High Quality Libor, CalPERS Short Duration, and CalPERS Internal Collateral, had weighted average maturities of $31,312,367,587,479$ days, respectively, and durations of 71, 0 , 32,0 , and 36 days, respectively.

Structured Investment Vehicles (SIVs) were purchased as Medium-Term Notes between April 2006 and March 2007 (with April 2009 and March 2010 maturity dates) and at the time of purchase met all Cash Collateral Reinvestment Policy guidelines. In 2007 and 2008, both SIVs went into enforcement, defaulted and eventually restructured. The re-structuring involved CalPERS receiving a pro-rata in kind interest of the underlying collateral of the SIVs. The average maturity on the underlying collateral is substantially longer than the original MediumTerm Notes and is considered long-term. “

$$
\cdots
$$

"CalPERS invested in the State Treasury pool and State Street Bank Global Advisors' (SSgA) short-term investment fund. These investments are included as part of the short-term investment line item on the financial statements. At June 30, 2011, the pooled money investment account with the State Treasury totalled approximately $\$ 1.8$ billion and the short-term investment fund with SSgA totalled approximately $\$ 6.9$ billion. The weighted average maturity is 237 days for the State Treasury pool and 33 days for the SSgA short-term investment fund."

Source: CalPERS Comprehensive Annual Financial Report, Fiscal Year Ended June 30, 2011, http://californiapolicycenter.org/wp-content/uploads/2013/11/CalSTRS_CAFR_FYE_6-30-2011.pdf

${ }^{18}$ CalPERS stands for The California Public Employees' Retirement System and PERF stands for Public Employees' Retirement Fund. 


\section{Appendix D. Litigation Trends in the Pension Fund Industry Related to Securities Lending}

The first lawsuit against Northern Trust was filed by the fiduciaries of a Section 401(k) plan sponsored by BP Corp. The lawsuit charges that Northern Trust and Northern Trust Investments N.A. (NTI) breached their ERISA fiduciary duties by engaging in the imprudent lending of securities and by not disclosing to the plan the losses incurred under NTI's securities lending program (BP Corp. North America Inc. Savings Plan Investment Oversight Committee v. Northern Trust Investments N.A., N.D. Ill., No. 1:08-cv-06029, lawsuit filed10/21/08)(208 PBD, 10/28/08; 35 BPR 2500, 11/4/08).

According to the complaint, NTI was to manage the plans' investments and it did so by placing the plans' assets in four collective investment funds. The four collective funds were managed by NTI and benchmarked to different stock or bond indexes. Under the investment guidelines set out in the investment management agreement with the BP plans, NTI was authorized to lend securities from the collective funds, in which the plans' assets were invested. According to the complaint, NTI represented to the plans that the purpose of its securities lending program was to earn a return through investment of the cash collateral received from borrowers of securities. The program would allow NTI to offset its expenses under the investment agreements with the plans, and further allowed the collective funds to better match the performance of their respective benchmark indices.

The complaint alleged that NTI appointed NTC as the securities lending agent for the collective funds and delegated to NTC the discretion to manage the securities lending activities. Under the securities lending program, NTC would loan securities purchased for the benefit of the four collective investment funds to borrowers who would provide cash collateral as security for the return of the loaned securities, the complaint said. NTI would then invest the cash collateral ("collateral funds") in other collective funds managed by NTI, according to the complaint.

... Among other things, the lawsuit alleged that some of the collateral funds' investments, which NTI made with cash collateral received from securities borrowers, have defaulted or have been marked down in value by NTI. According to the complaint, as a result of losses NTI has incurred through its securities lending activities, the fiduciaries of BP's defined contribution plans on Oct. 15, 2008, halted any additional BP participant contributions to and transfers into the collective funds.

In addition, the fiduciaries requested that NTI and NTC distribute to the plans an amount in cash reflecting the value of the plans' investment accounts, excluding any effects of securities lending or investment in cash collateral pools or funds supporting securities lending.

The complaint alleged that NTI has refused to distribute the plans' assets in cash, and has informed the plan fiduciaries that NTI's distribution would include interests in impaired securities. Accordingly, if NTI makes a distribution to the plans, it will include interests in the impaired securities which are not part of the relevant indices specified in the investment guidelines the plans gave to NTI, the complaint charged.

In December, the district court denied the BP plan fiduciaries' motion for a preliminary injunction that would have required NTI to return to the plans assets that have allegedly been impaired by NTI's securities lending program (243 PBD, 12/19/08; 35 BPR 2939, 12/30/08).

Source: Pension \& Benefits Daily: All Issues $>2009>$ February $>02 / 26 / 2009>$ Special Report $>$ ERISA Plan Fiduciaries Take Aim at Each Other as Investment Losses Rise 


\section{Appendix D. continued}

Transparency and Lack of Regulatory Oversight Issues in the Securities Lending Industry, Challenge for the Less Connected Market Participants

\section{U.S. pension funds sue Goldman, JPMorgan, others over stock lending market}

(Reuters) - Three U.S. pension funds sued six of the world's largest banks on Thursday, including Goldman Sachs Group Inc. (GS.N) and JP Morgan Chase \& Co (JPM.N), accusing them of conspiring to stifle competition in the more than $\$ 1$ trillion stock lending market.

In the lawsuit filed in a Manhattan federal court, the funds accused the banks of boycotting start-up lending platforms by threatening and intimidating their potential clients. The defendants include Bank of America Corp (BAC.N), Credit Suisse AG CSAG.UL, Morgan Stanley (MS.N), UBS AG (UBSG.S), Goldman and JP Morgan.

The Iowa Public Employees' Retirement System, Orange County Employees' Retirement System and Sonoma County Employees' Retirement Association said in the lawsuit that the banks have cornered the market on stock lending in violation of federal antitrust law.

"Through various improper means, the likes of Goldman Sachs and Morgan Stanley have for years colluded to maintain their power over this little-known-but-lucrative corner of Wall Street," said Michael Eisenkraft, a lawyer for the funds and partner with Cohen Milstein.

\section{Representatives of Bank of America, Goldman Sachs and JPMorgan declined to comment.}

The other banks did not immediately respond to requests for comment.

The pension funds said collusion by the banks harms investors and retirees by forcing them to pay high fees to engage in stock lending.

Stock lending is related to short selling and involves lending a stock to an investor or firm through a broker or dealer. Pension funds and other institutional investors frequently lend stock to hedge funds.

In short selling, a security that is not owned or has been borrowed is sold with the idea that it can be bought at a future date at a lower price.

The funds claimed in the lawsuit that the defendants conspired to take down upstart stock lending platforms AQS, which was developed by Quadriserv Inc, and SL-x, which would have allowed lenders and borrowers to interact directly.

The lawsuit claimed that in 2012 Goldman Sachs threatened to stop doing business with Bank of New York (BNY) Mellon if it continued to support the AQS platform and that the bank agreed to stop using it. BNY Mellon declined to comment.

Source: Reuters, August 18, 2017

https://www.reuters.com/article/us-stocklending-lawsuit/u-s-pension-funds-sue-goldman-jpmorgan-othersover-stock-lending-market-idUSKCN1AX2NK 


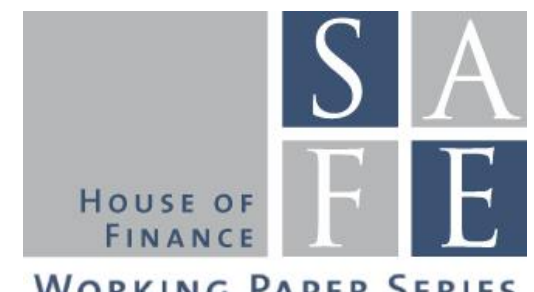

WORKING PAPER SERIES

\section{Recent Issues}

No. 214 Edin Ibrocevic, Matthias Thiemann

No. 213 Klaus Gugler, Michael Weichselbaumer, Christine Zulehner

No. 212 Henning Hesse

No. 211 Thomas Mosk

No. 210 Darien Huang, Christian Schlag, Ivan Shaliastovich, Julian Thimme

No. 209 Eren Gürer, Alfons J. Weichenrieder

No. 208 Roberto Casarin, Michele Costola, Erdem Yenerdag

No. 207 Claes Bäckman, Tobin Hanspal

No. 206 Loriana Pelizzon, Anjan Thakor, Calebe de Roure

No. 205 Horst Entorf, Jia Hou

No. 204 Loriana Pelizzon, Matteo Sottocornola

No. 203 Florian Hett, Felix Schmidt

No. 202 Tobias H. Tröger

No. 201 Dirk Krueger, Alexander Ludwig
All Economic Ideas are Equal, but Some are more Equal than Others: A Differentiated Perspective on Macroprudential Ideas and their Implementation

Effects of Government Spending on Employment: Evidence from Winners and Runners-up in Procurement Auctions

Incentive Effects from Write-down CoCo Bonds: An Empirical Analysis

Bargaining with a Bank

Volatility-of-Volatility Risk

Pro-rich Inflation in Europe: Implications for the Measurement of Inequality

Financial Bridges and Network Communities

The Geography of Alternative Work

P2P Lending versus Banks: Cream Skimming or Bottom Fishing?

Financial Education for the Disadvantaged? A Review

The Impact of Monetary Policy Interventions on the Insurance Industry

Pushing Through or Slacking Off? Heterogeneity in the Reaction to Rank Feedback

Germany's Reluctance to Regulate Related Party Transactions

Optimal Taxes in the OLG Model with Uninsurable Idiosyncratic Income Risk 